الوقف والابتداء في القرآن الكريم دراسة نصية

الوقف والابتداء في القرآن الكريم الكران

دراسة نصية

الباحث /محمد عبد الحليم عبد المنعم أبو عرب

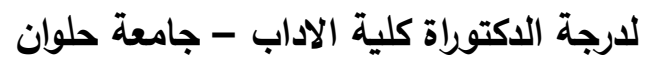

\title{
تحت اشراف
}

$$
\text { أ.دا نادية رمضان }
$$

استاذ العلوم اللغوية كلية الاداب - جامعة حلوان

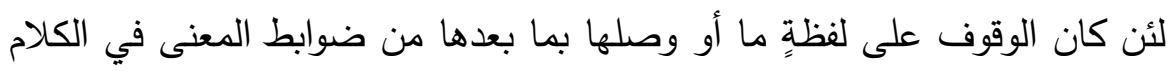

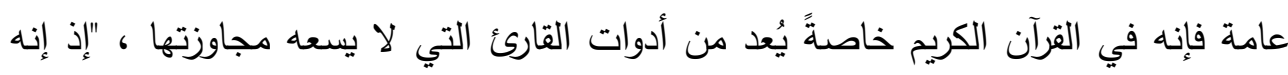

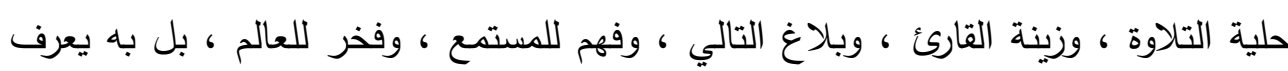

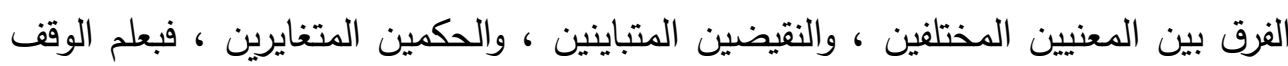

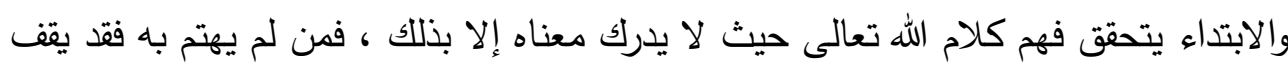

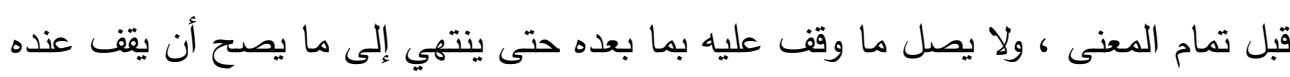

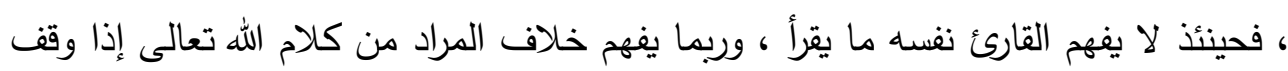

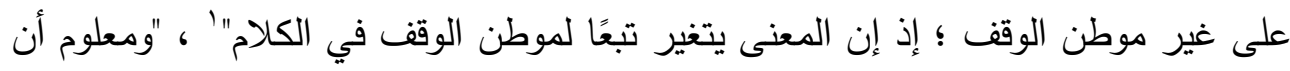

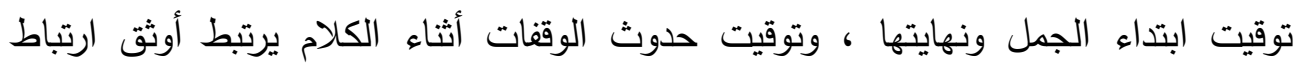

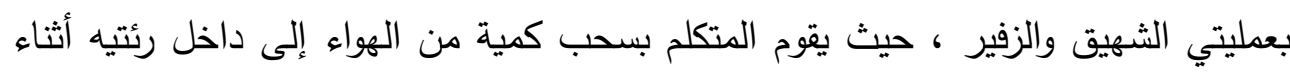
هذه الوقفات ؛ ليتسنى له تعويض هواء الزفير ، وتوفير تيار الهواء المضغوط اللازم

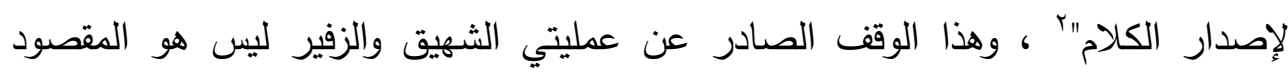

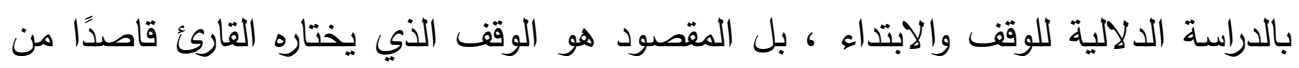
وراء اختياره توضيح دلالات بعينها .

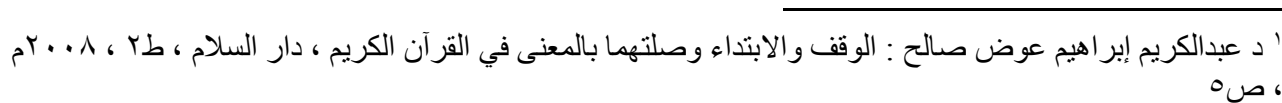

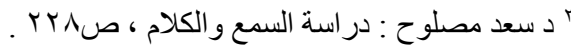


وقد أكون مصيبًا إن قلت إن اختيار الوقف على على سبيل اللزوم هو مظهر من مظاهر العدول ؛ لأن الكلام في لغة العرب عامة ولغة القرآن خاصة يُبنى على الوصل

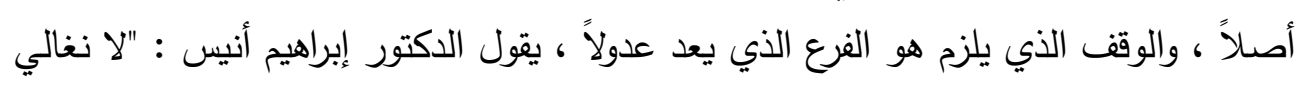

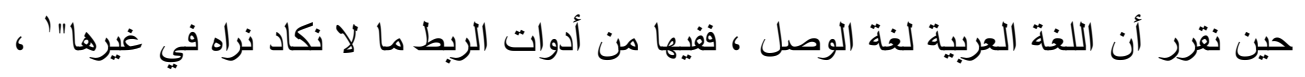

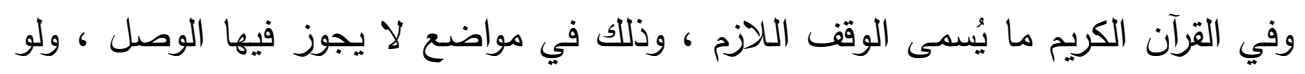

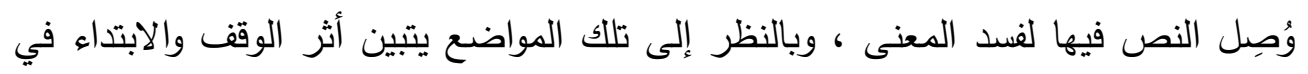
حبك النص وصن والوقف والابتداء في النص ضابط من ضوابط فهمه ؛ إذ "يدل الوقف بوسائله المتعددة على موقع هو في طابعه "مِفْصَل" من مفاصل الكلام يمكن عنده قطع السلسلة

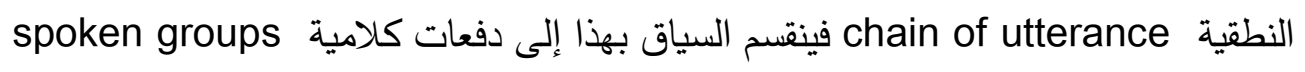
تعتبر كل دفعة منها إذا كان معناها كاملاً "واقعة تكميلية speech event " منعزلة ، أما بهاب إذا لم يكن معناها كاملاً ، كالوقف على الشرط قبل ذكر الجواب مثلاً فإن الواقعة التكميلية

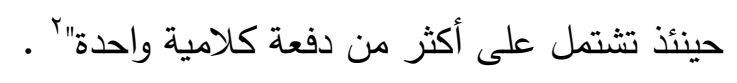
وهذا ما دعا إليه المفسرون من قبلُ في تتاولهم للوقف والابتداء ، فقد قسم

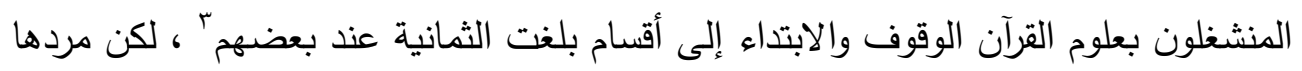

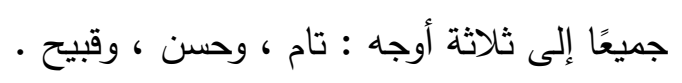

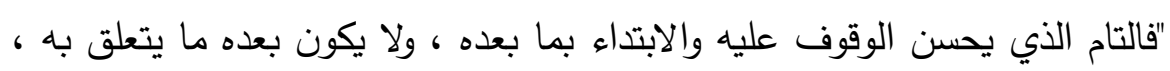

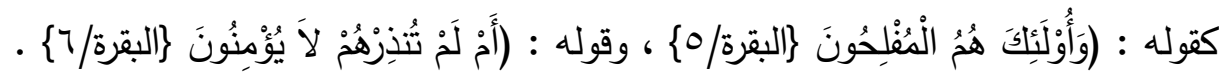
والحسن : هو الذي يحسن الوقوف عليه ولا يحسن الابتداء بما بعده ، كقوله :

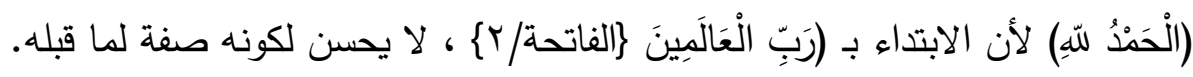

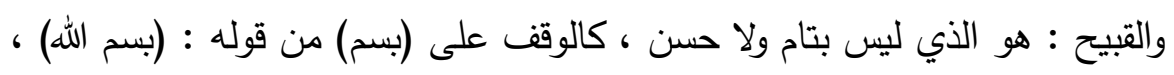
ولا يتم الوقف على المضاف دون المضاف إليه ، ولا المنعوت دون نعته ، ولا الرافع دون

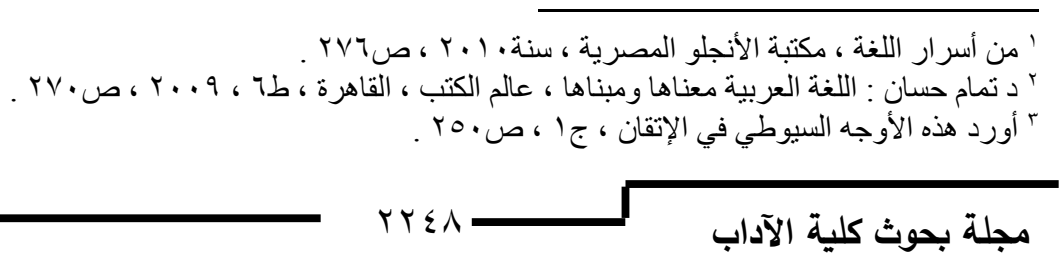




\section{الوقف والابتداء في القرآن الكريم دراسة نصية}

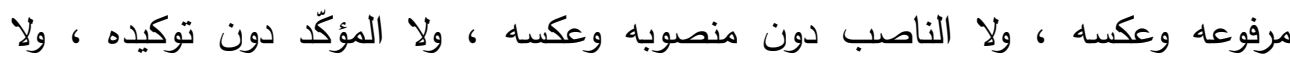

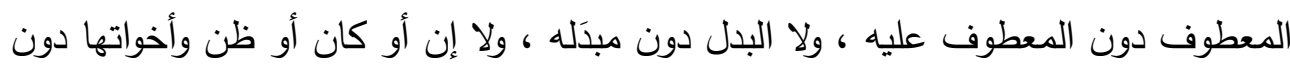

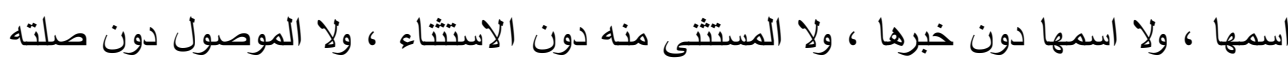

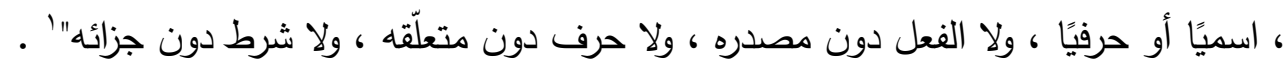

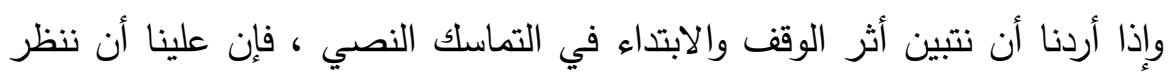

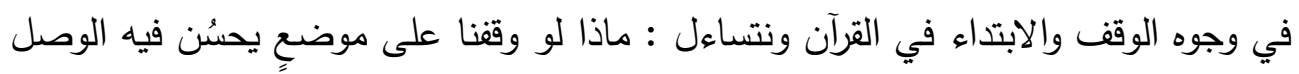

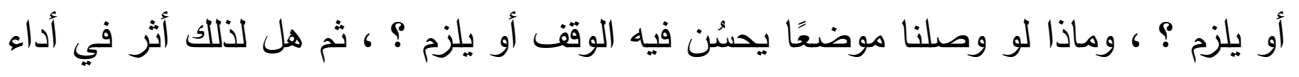

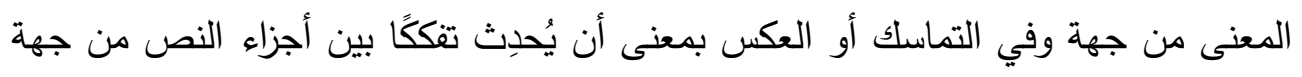

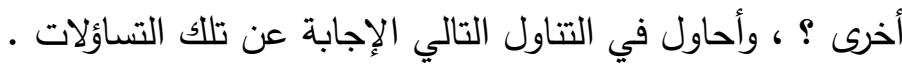

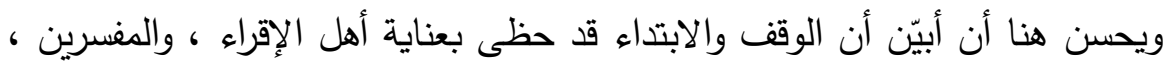

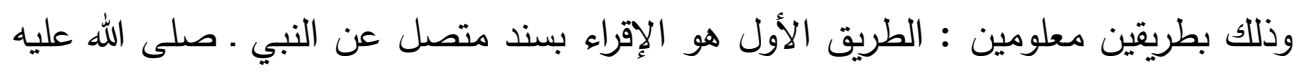

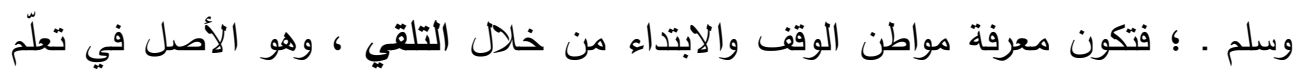

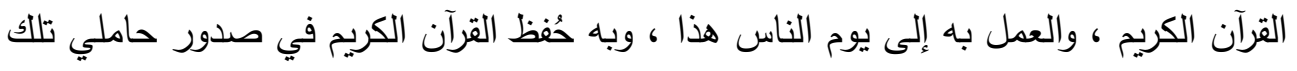

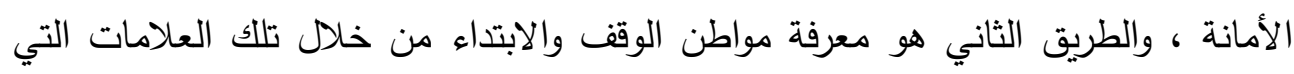

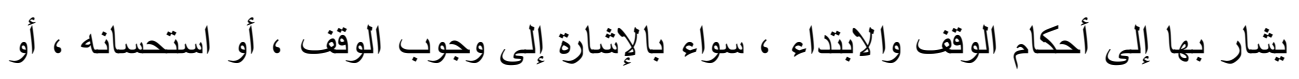

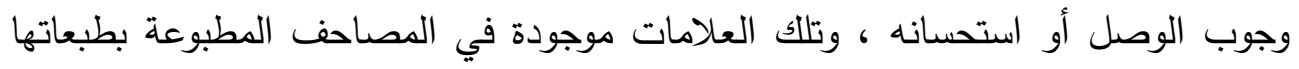

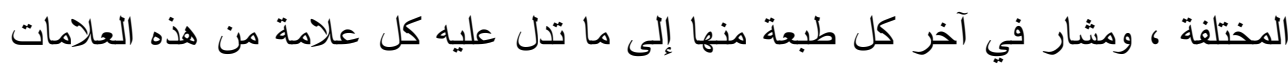

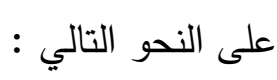

\section{علامات الوقف التف}

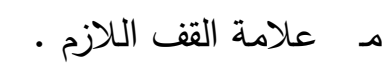

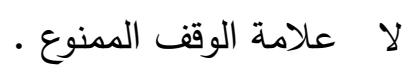

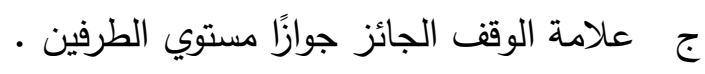

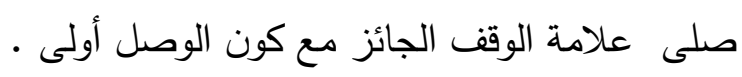

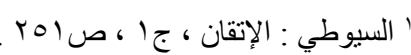




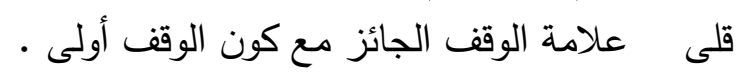

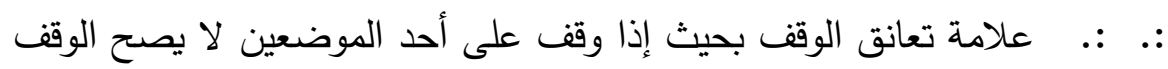

$$
\text { - على الآخر' }
$$

فذانك طريقان لمعرفة الوقف والابتداء ، من خلال الرجوع إلى أهل الإقراء

والضوابط التي أقرتها لجنة مراجعة الدصحف الشريف ، أما هذه الدراسة فتعنى بدراسة

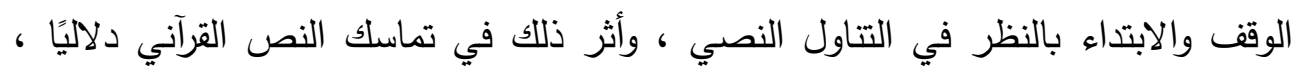

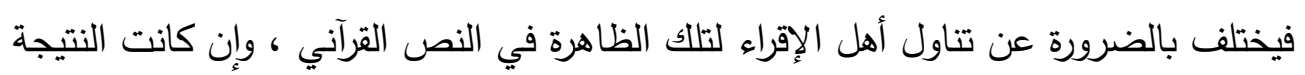

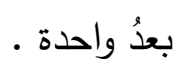

ومن خلال النظر في مواضع الوقف والابتداء في القرآن الكريم تبيّن أن للوقف

والابتداء أثرًاً في التماسك النصي ، بحيث يسهم بشكل مباشر في وضوح دلالة النص ، كما

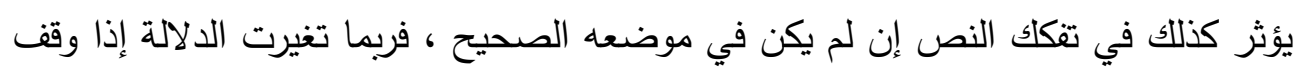

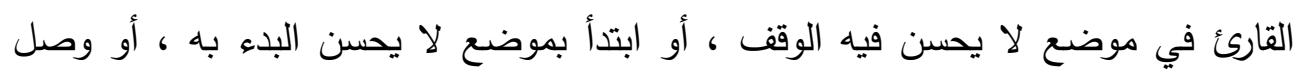

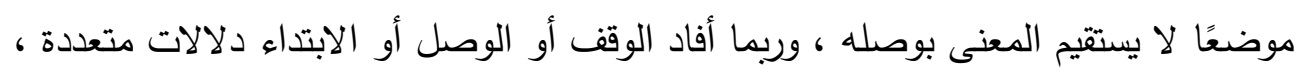

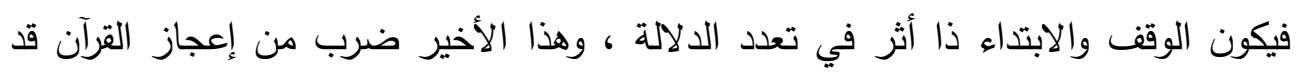

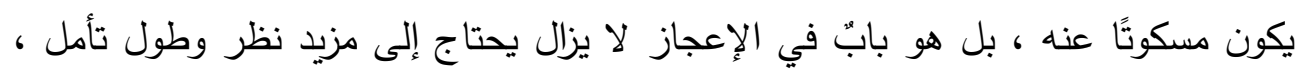

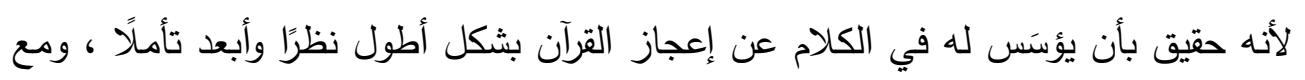
ذلك فإن كثيرًا من المتكلمين في إعجاز القرآن انصرفوا عنه إلى التكلم في وجوهٍ لعلها أدقُ

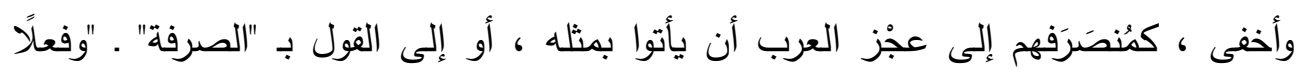

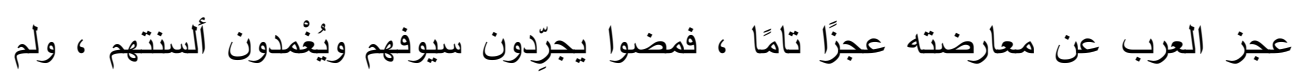

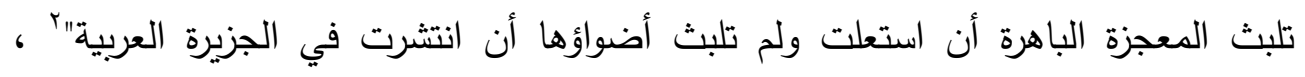
وقولهم بالإعجاز بالإخبار بالغيب ، أو إلى القول بأن إعجازه من جهة البلاغة ، أو القول التهات

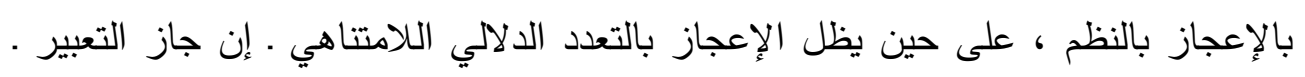


الوقف والابتداء في القرآن الكريم دراسة نصية

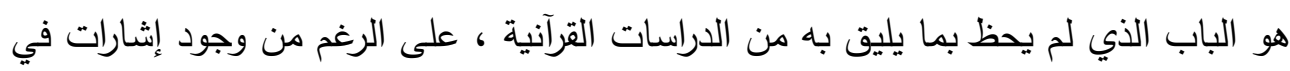

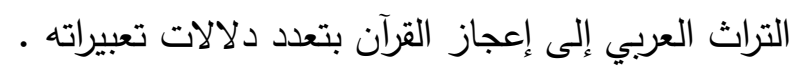

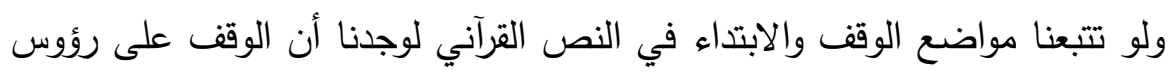

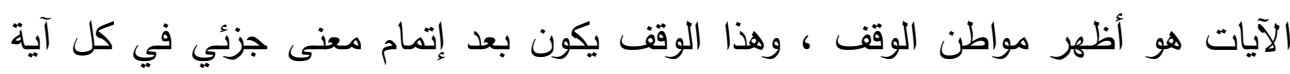

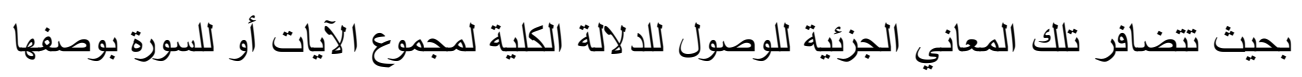
نصًا

فكل آية من آيات سور القرآن لها معنى هو جزء من معنى مجموعة من الآيات

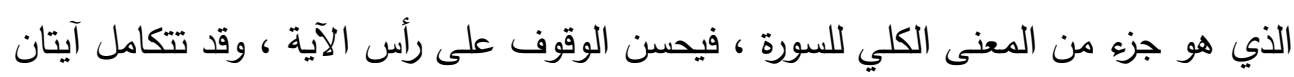

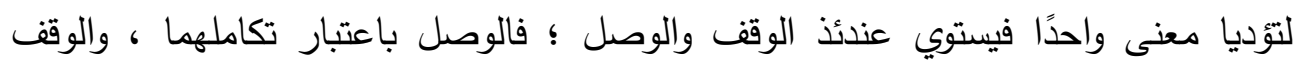

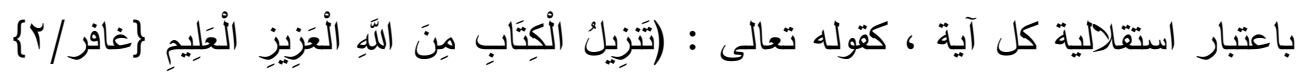

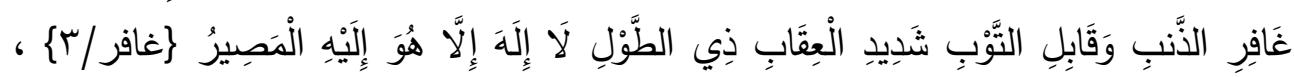

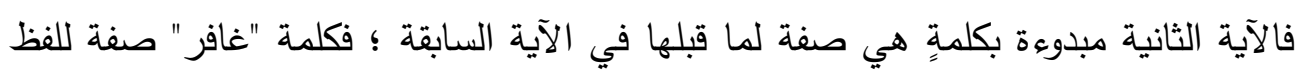

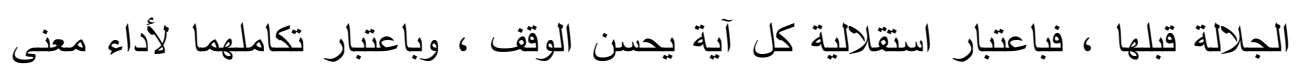
واحد يحسن الوصل .

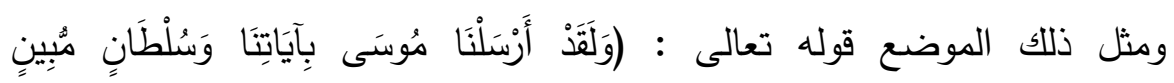

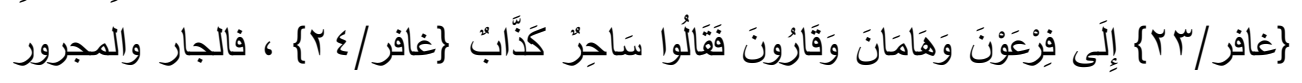

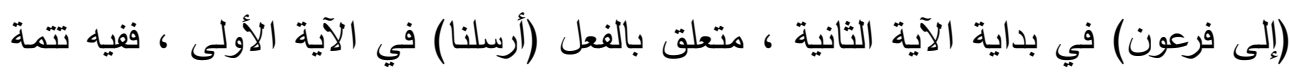

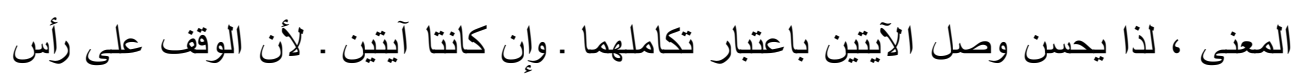

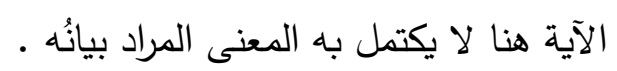

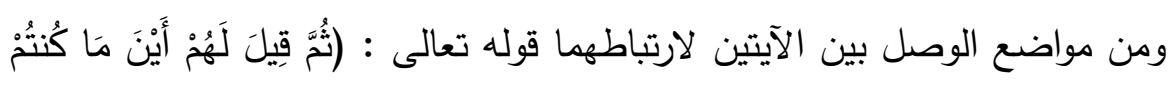

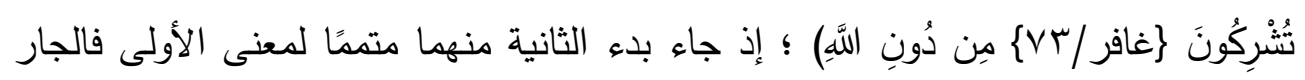

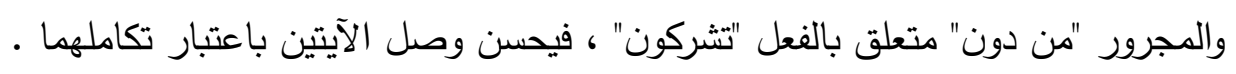

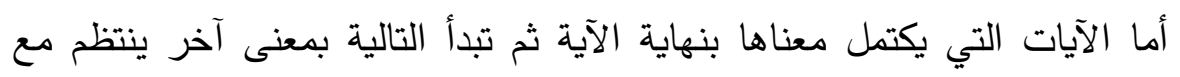

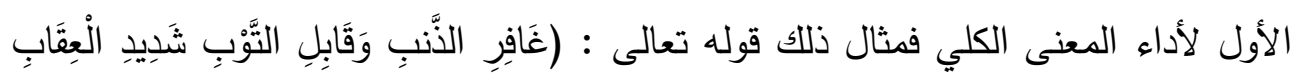




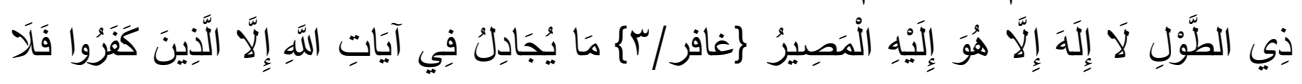

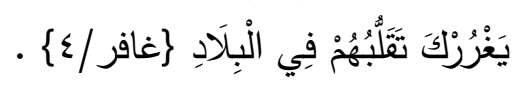
فقد اكتمل معنى الآية عند قوله تعالى (إليه المصير) وبدأت التالية بمعنى جديد ، والذي أود أن أشير إليه هنا أن المثال الأول الذي تكاملت فيه الآيتان يحسن فيه وصليه وصليها

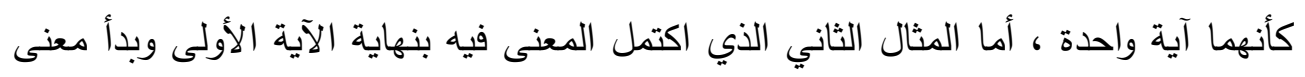

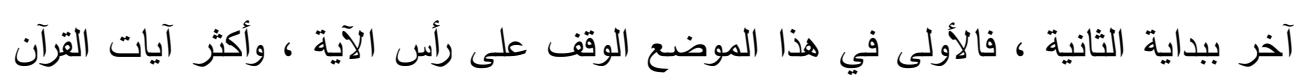
من هذا النوع •

ولا يقتصر الوقف الحسن على رؤوس الآيات فحسب ، بل يحسن الوقوف في

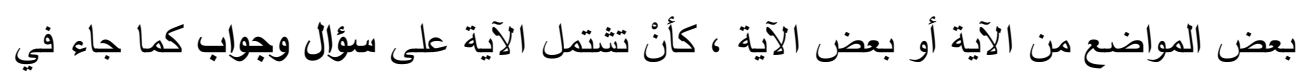

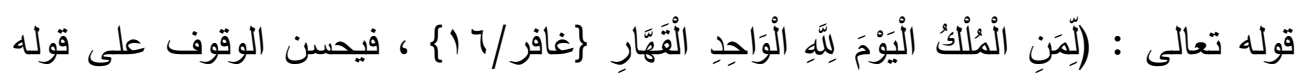
(اليوم) لأنه منتهى سؤال ، ثم البدء بالجواب بعده (لله) ، وكذلك كل سؤال وجوابه ، ليحصل

$$
\text { للمتلقي حسن الفهم بحسن الوقوف والابتداء . }
$$

وكذلك يحسن الوقوف عند بعض الآية إذا اشتملت الآية الواحدة على المعنى

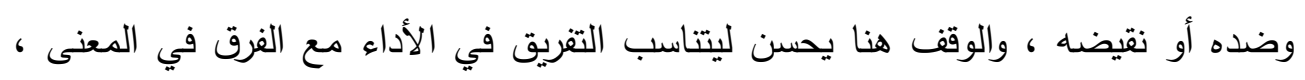

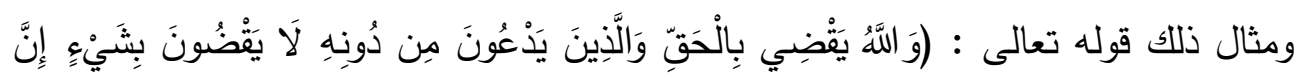

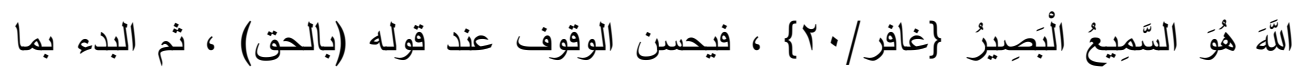
بعدها لأن الآية جمعت بين نقيضين أو ضدين : قضاء الله بالحق ، وعدم قضاء الذين

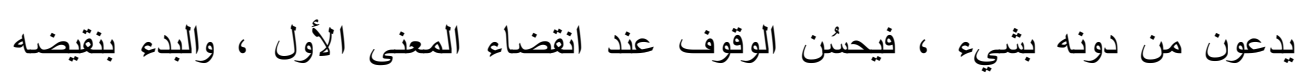

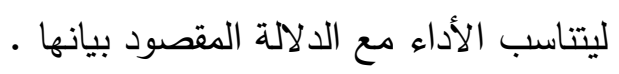

وكذلك يحسن الوقوف عند بعض الآية إذا اشتملت الآية الواحدة على حوار انتقل

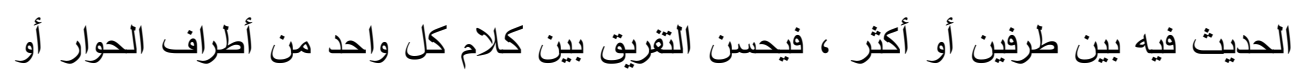

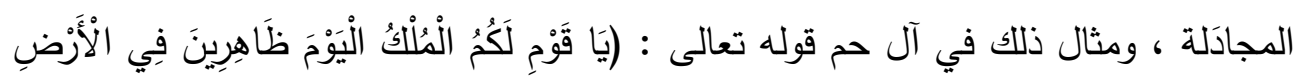

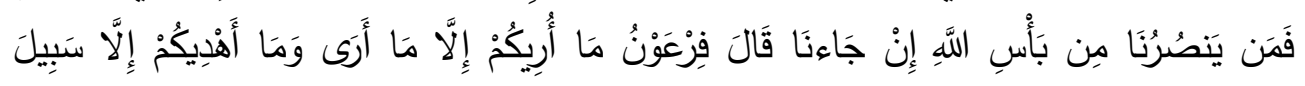


الوقف والابتداء في القرآن الكريم دراسة نصية

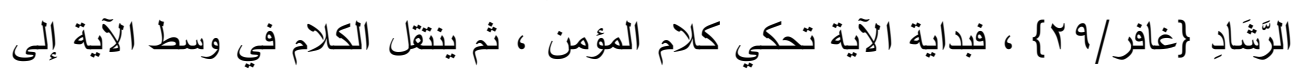

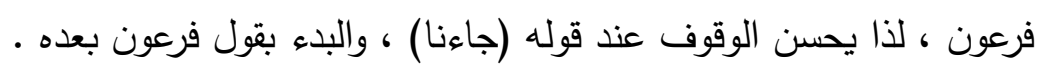

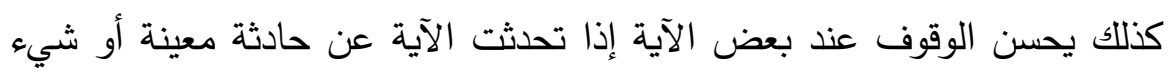

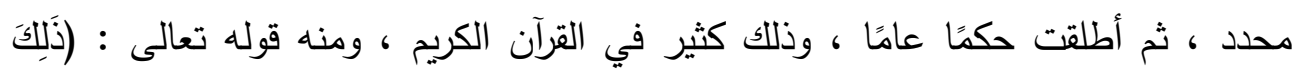

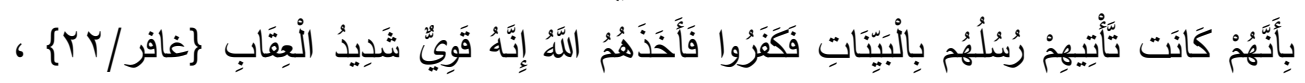

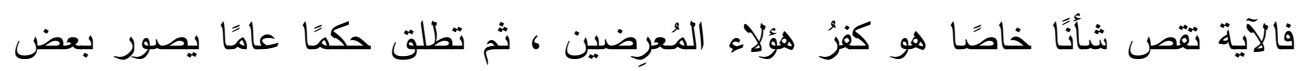

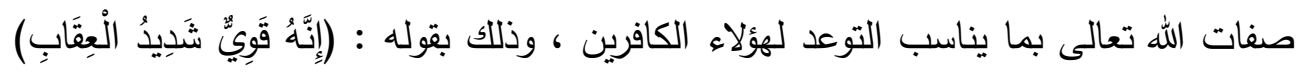

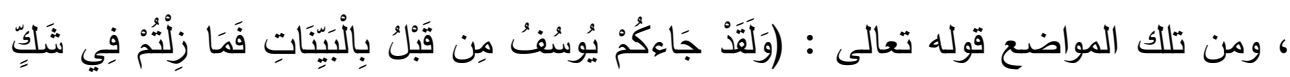

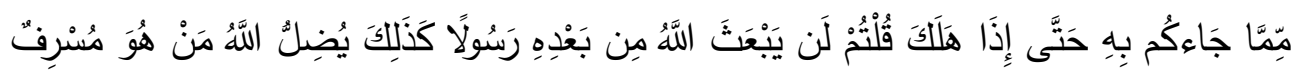

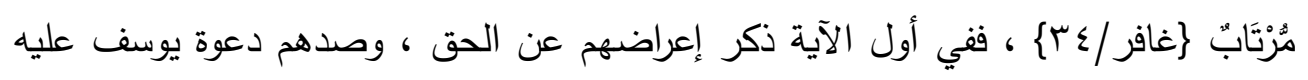

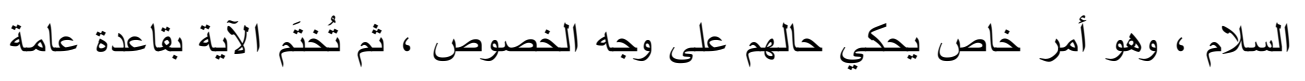

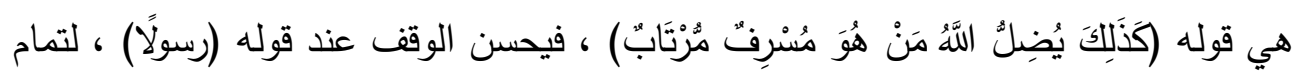

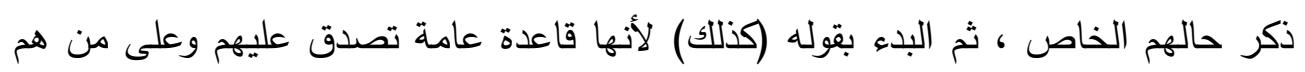
في حكمه .

\section{الوقف القبيح :}

وهناك ضرب ثالث من ضروب الوقف والابتداء يلزم فيه الوقف ، ويقبح فيه الوصل

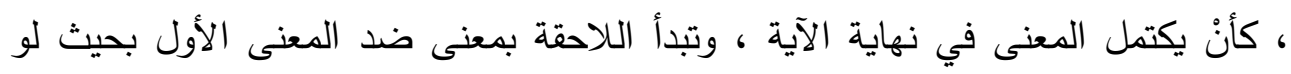

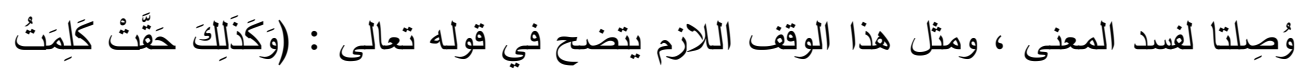

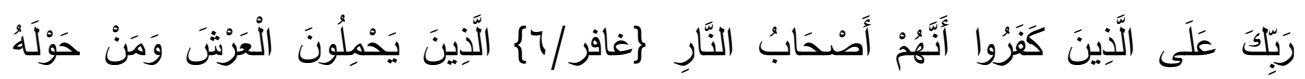

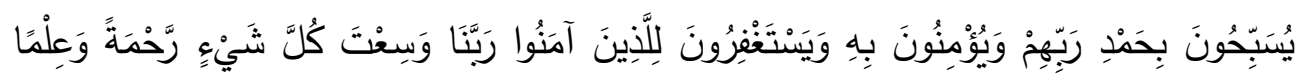

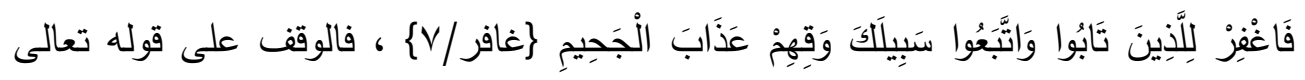

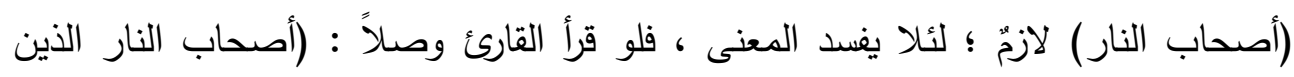

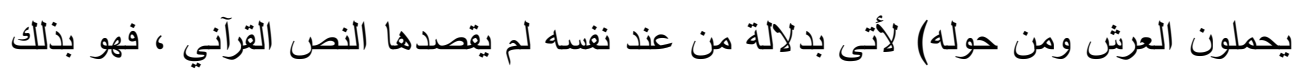

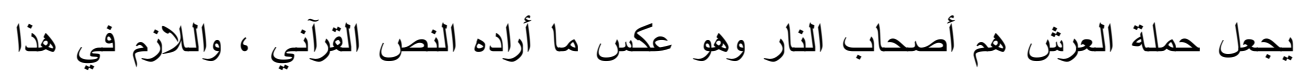


الموضع هو الوقف على رأس الآية ، بل وتغيير الأداء الصوتي بعدهاب بما يناسب الإب الانتقال

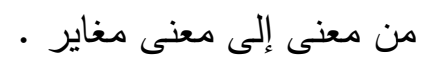

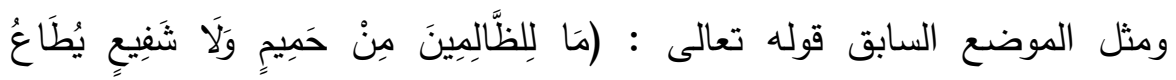
\}غافر/11

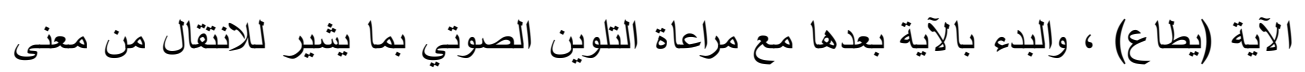

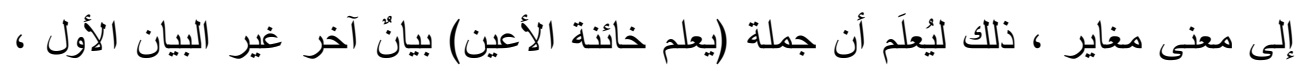

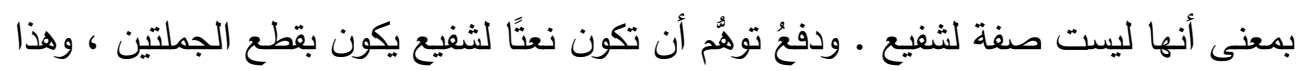

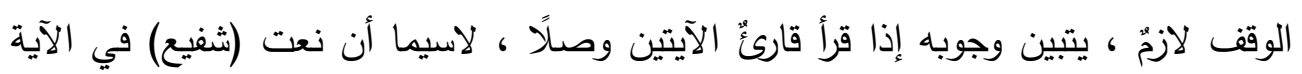
الأولى جاء جملة فعلية (يطاع) ، والآية بعدها مبدوءة بجملة فعلية أيضًا (يعلم) ، فالجملتان النين

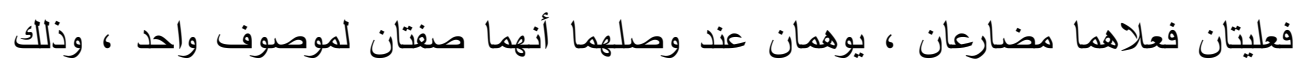

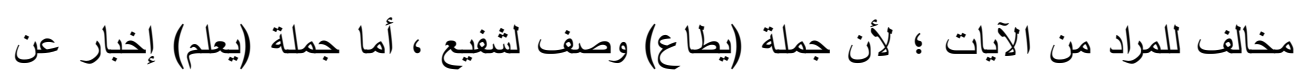

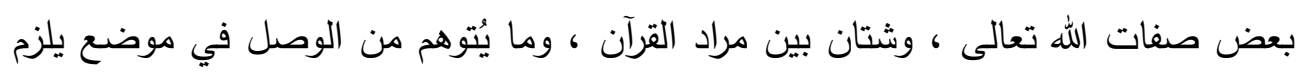
فيه القطع . وهناك موضع لا يليق الوقوف عليه ، إذ لو وقف عليه القارئ لأوهم خلاف المراد ،

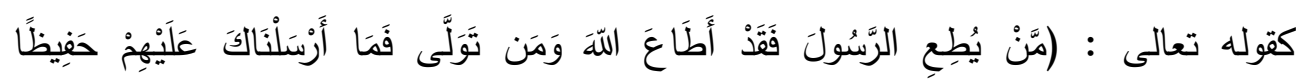

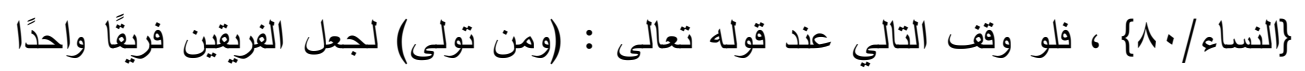
فينتفي عندئذ التحذير من الإعراض الذي قصدت إليه الآية ، ومن مواضعه في آل حم قوله لهونه

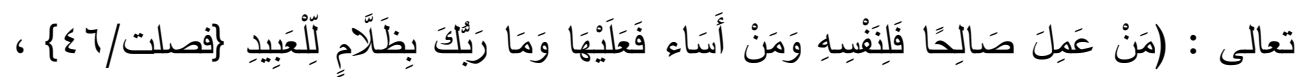

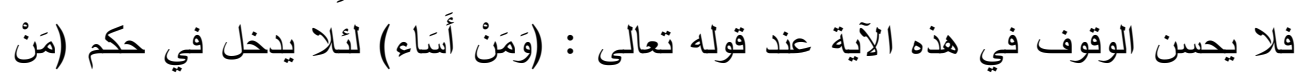
• عَمِلَ صَالِحًا )

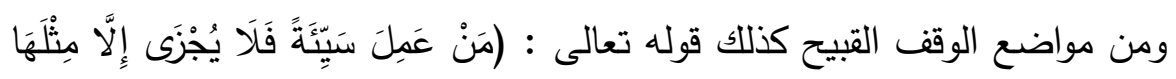

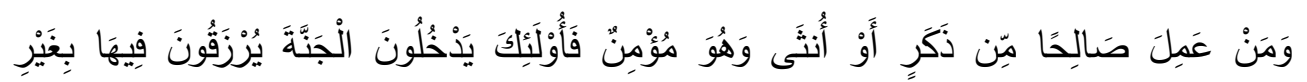

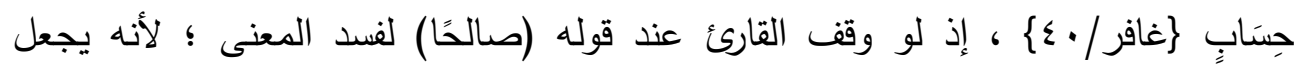

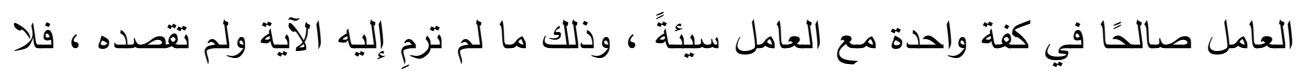


الوقف والابتاء في القرآن الكريم دراسة نصية

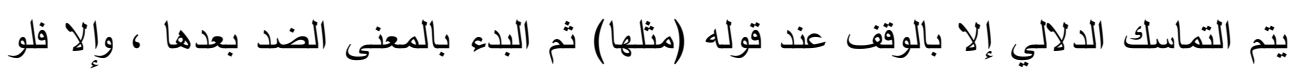

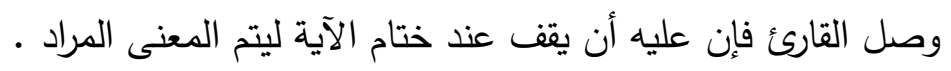

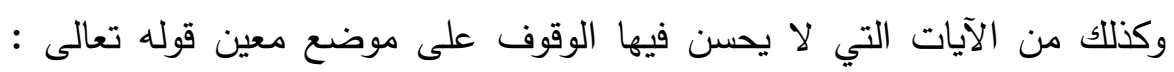

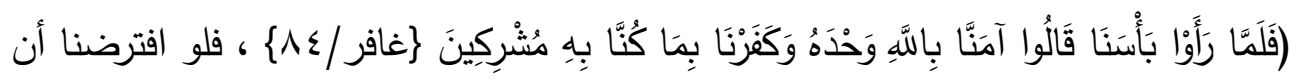

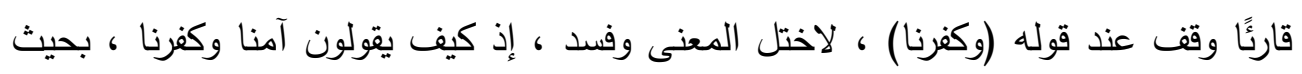

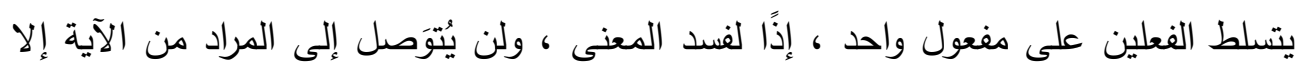
بوصلها إلى منتهاها .

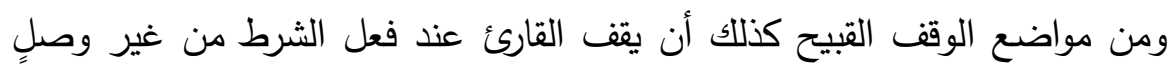

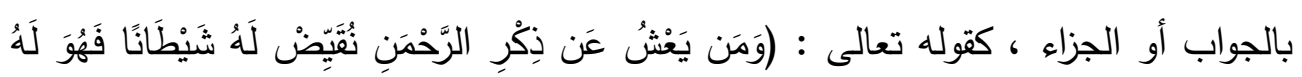

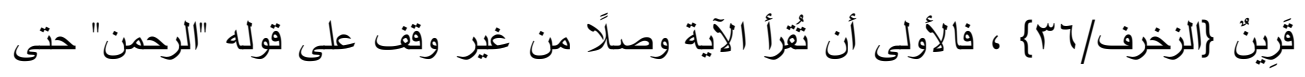

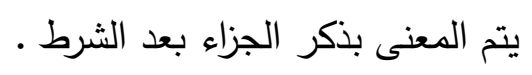

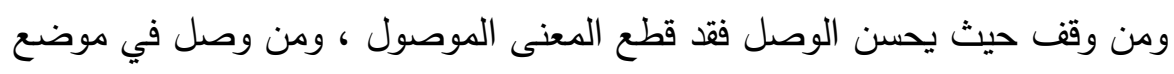

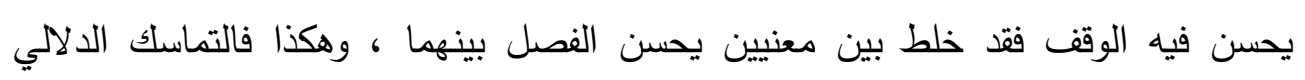
للنص مرهون بحسن الوقف وحسن الابتداء . تقسيم الوقف والابتداء نصيًا :

أرى أن الوقف والابتداء ـ وقد سبق تقسيمه باعتبار المعنى العام ـ يمكن أن يُعََّّم

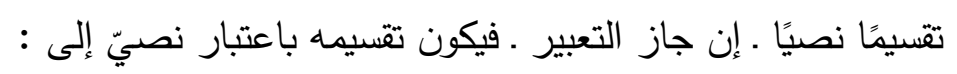
وقف موضوعي ، ووقف معنوي ، ووقف إعرابي

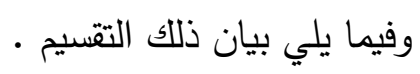

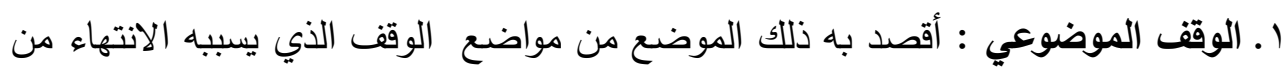

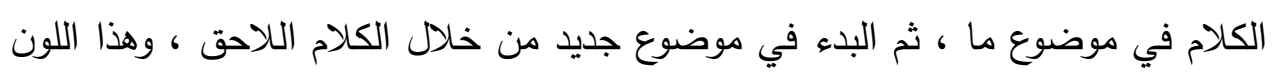

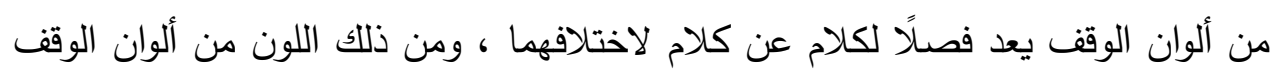

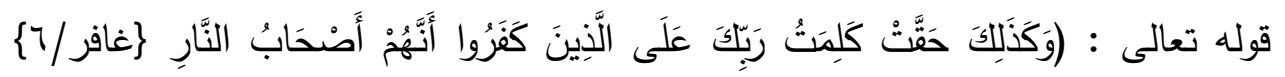

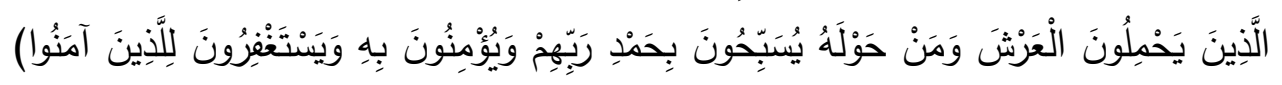


، فالكلام عن الكافرين انتهى عند قوله : (أصحاب النار) ، لذا وجب الوقب الوقف ليبدأ كلام

$$
\text { آخر عن الملائكة . ألمن }
$$

ومن مواضع الوقف الموضوعي كذلك قوله تعالى : (وَ اللَّهُ يَقْضِي بِالْحَقِّ وَالَّذِينَ

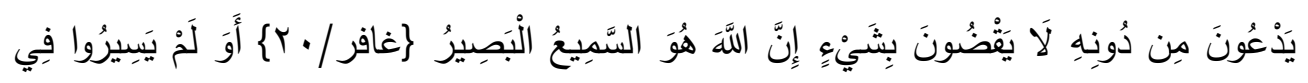

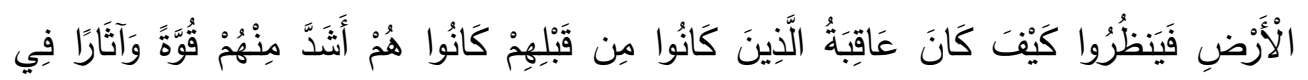

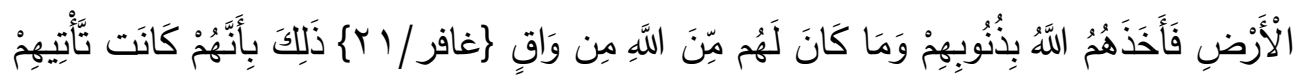

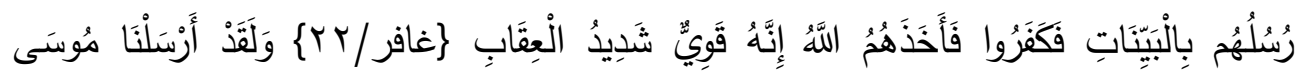

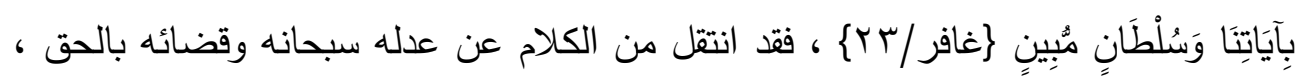

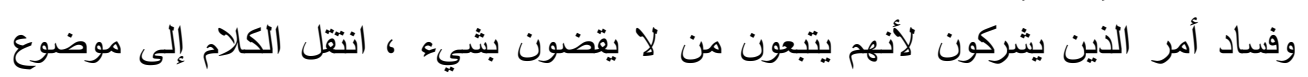

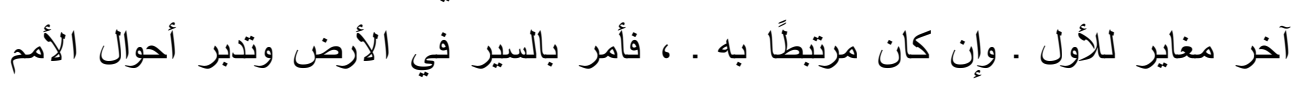

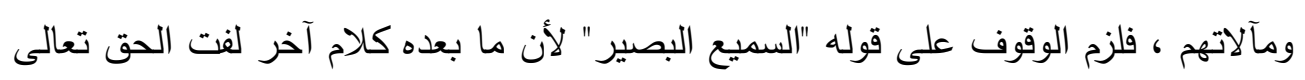

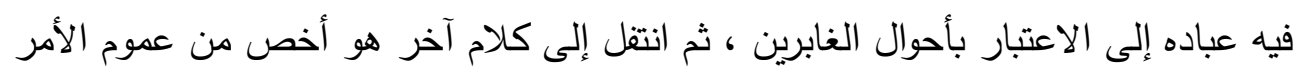

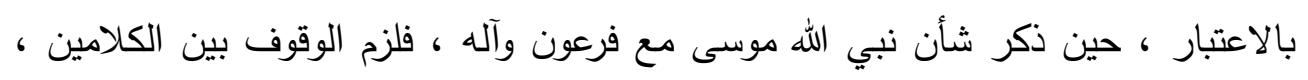

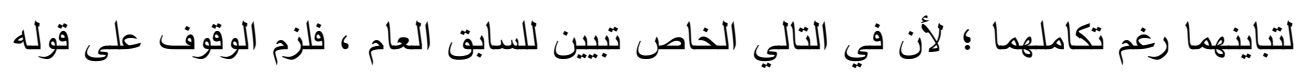

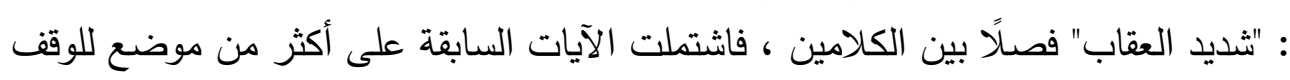
الموضوعي لانتقال الخطاب القرآني بين موضوعات مختلفة . ومن المواضع التي يتبين فيها أثر الوقف الموضوعي أن يصل القارئ آيات متتالية

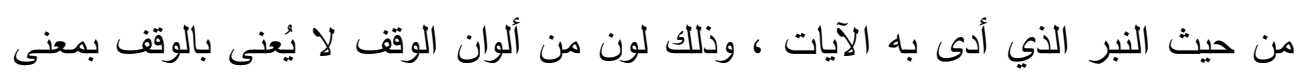

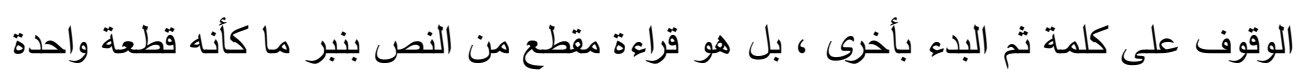

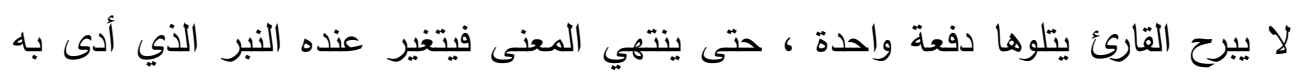

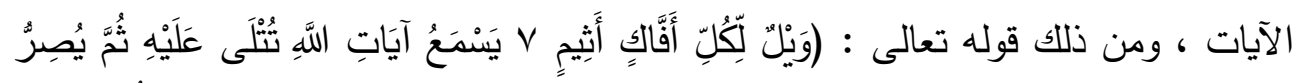

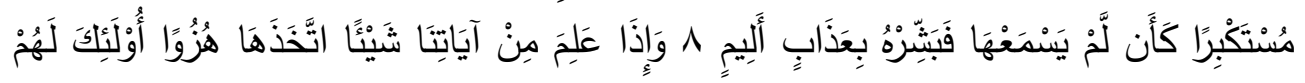

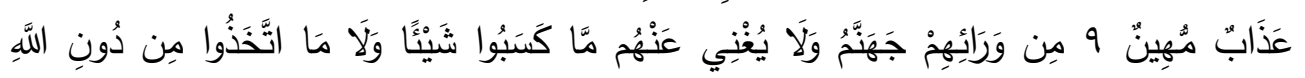

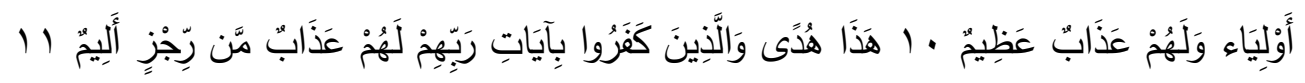




\section{الوقف والابتداء في القرآن الكريم دراسة نصية}

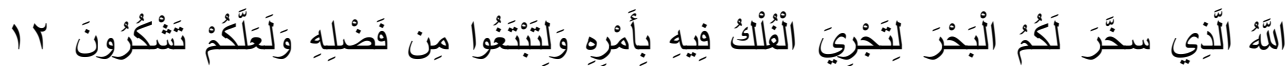

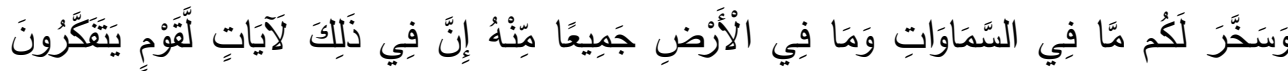

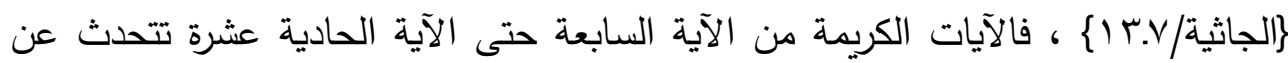

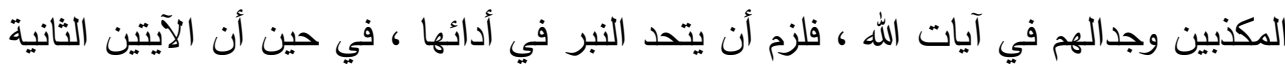

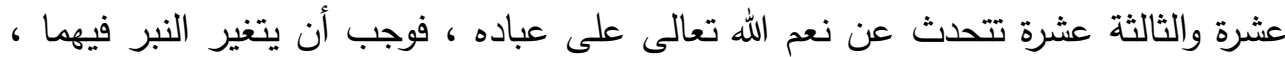
ولا شك أن هذا لون من ألوان الفصل أو الوقف يؤدي وظيفة الوقف على كلمة والبدء بما لئا

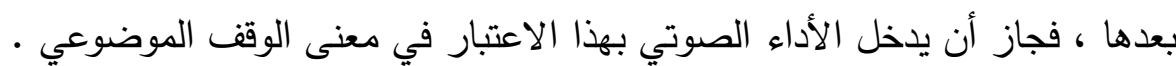

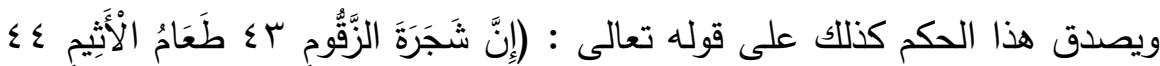

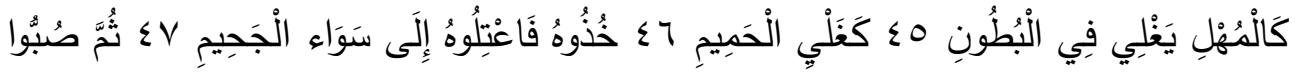

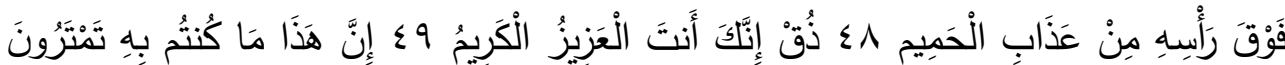

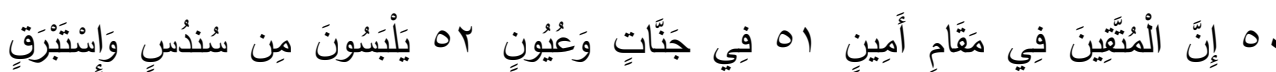

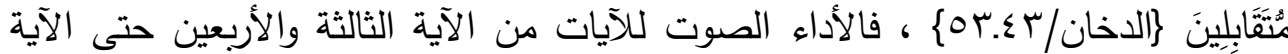

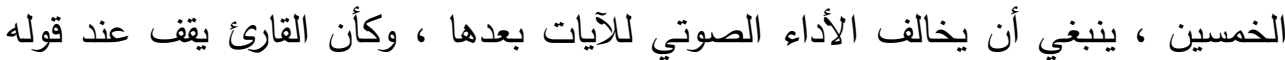

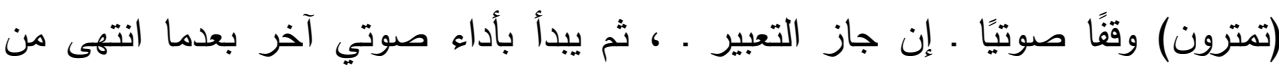
الحديث عن عقاب المكنبين ليناسب أداؤه الحديث عن نعيم المتقين ، وذلك لون من ألوان التوان

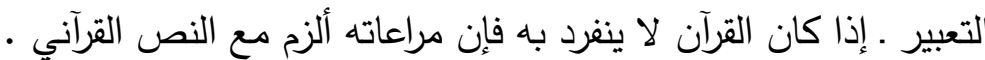

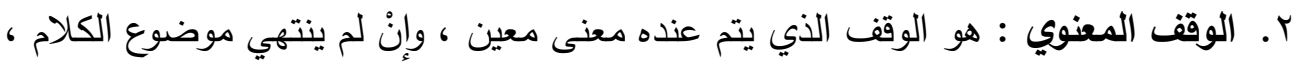

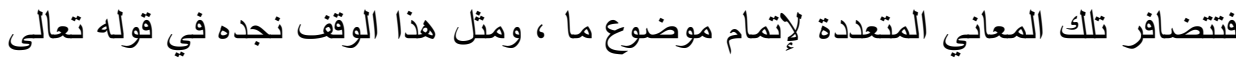

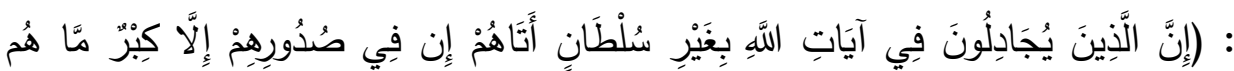

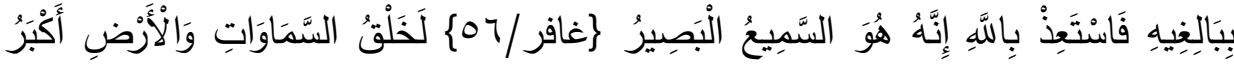

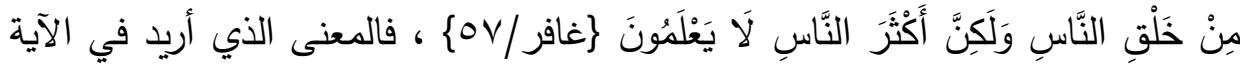

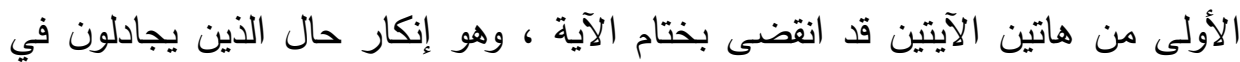
آيات الله ، ثم بدأ معنى جديد لكنه ذو ارتباط بالمعنى الأول ؛ لأن الآية الثانية ذكرت الآن الآن

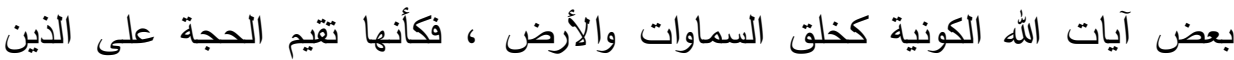




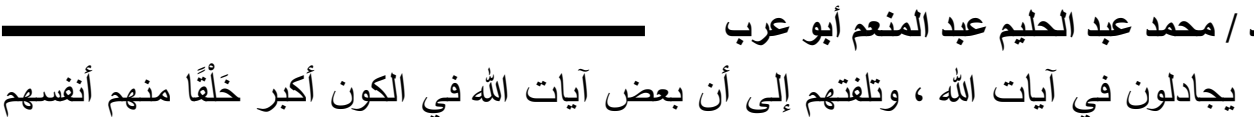

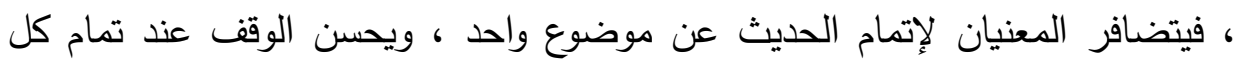

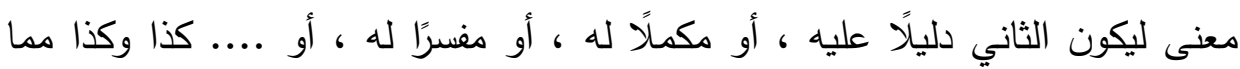

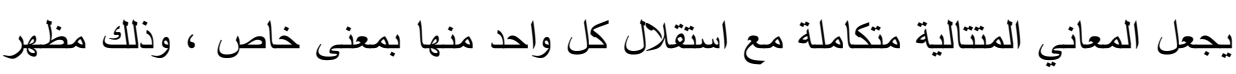

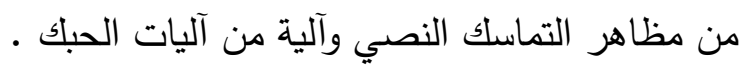
ويمكن اعتبار الوقوف على كل جزء من أجزاء القصة الواحدة أو كل كلام من الحوار ، لونًا من ألوان الوقف المعنوي ؛ كأن يقف القارئ على كلام كل محاور قبل الانتقال إلى رد محاوِرِه ، ومن أمثلة ذلك في القرآن حوار موسى وفرعون ومؤمن آل فرعون : (وَقَّالَ

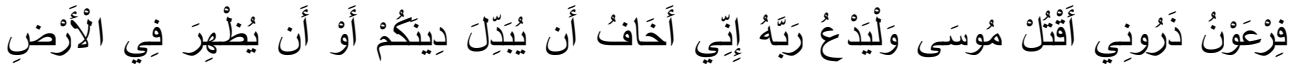

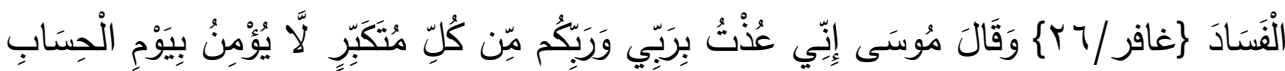

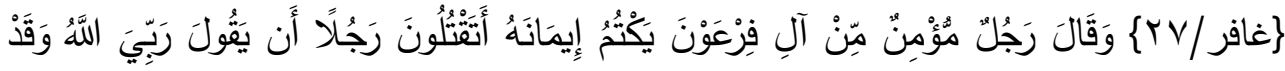

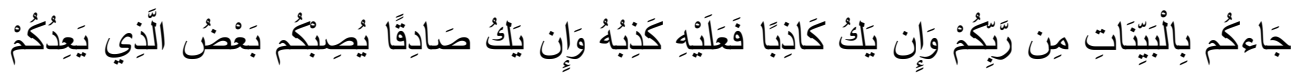

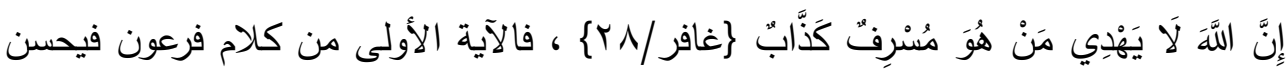
الوقوف على رأس الآية ، ثم التالية من كلام موسى فيبدأ القارئ بكلامه ثم يقف على الألى رأس

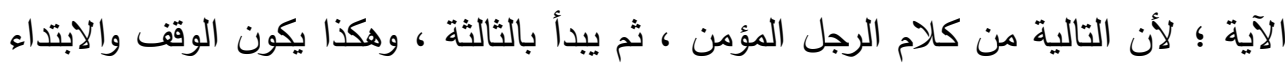

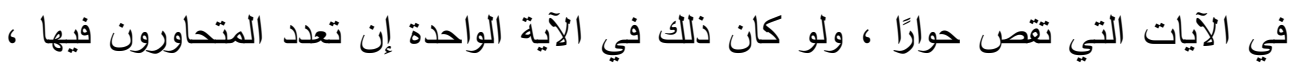
لئلا يلتبس كلام أحدهم بكلام الآخر ، وليبدو المعنى منتظمًا بترتيب كلام المتحاورين . وتتضح أهمية ذلك اللون من ألوان الوقف (الوقف المعنوي) عند المواضع التي لهي يستقيم الوقف فيها من حيث السلامة الإعرابية ، ومع ذللك يختل المعنى من حيث مقاصد

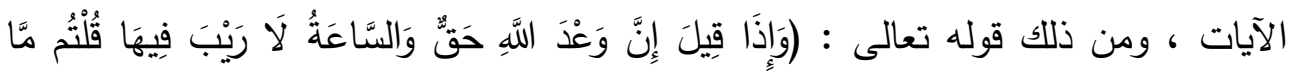

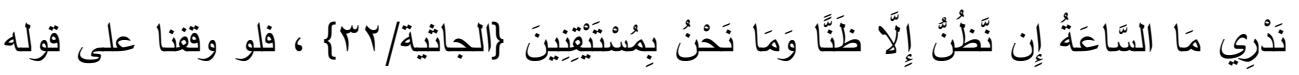

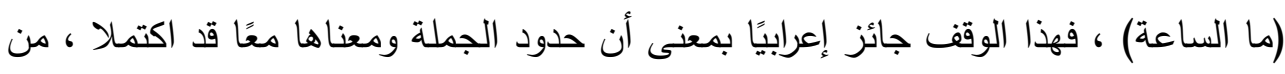

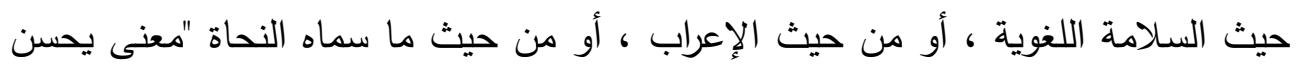
السكوت عليه ؛ إلا أن الأمر في الدرس النصي لا يقف عند حدود الجملة ، والمقصد مندابه 
الوقف والابتداء في القرآن الكريم دراسة نصية

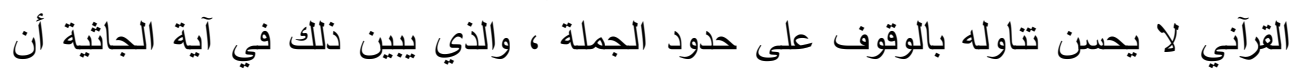
البدء بقوله (إن نظن) بعد الوقف على (الساعة) يحيل إلى سوء فهم للآية الكريمة ، فربما توجه الفهم عندئذ إلى أن هذا الكلام من عند الله تعالى ، وهذا يتتافى مع المعنى العام للآية ومع مقصدها كذلك ، والذي يوجه الفهم بالضرورة إلى أن تلك الجملة من جملة كلى كلام المكذبين هو وصل الآية من غير وقف على قوله (الساعة) .

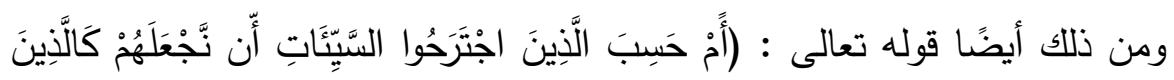

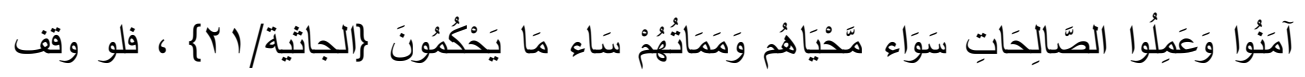
القارئ على قوله (الصالحات) لاكتمل بناء الجملة من حيث الإعراب ، بيد أن البدء بقوله

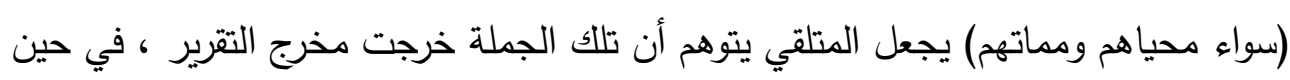

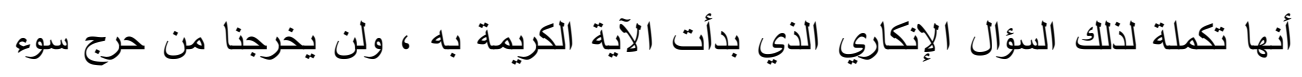
الفهم إلا رعاية الوصل في الآية الكريمة .

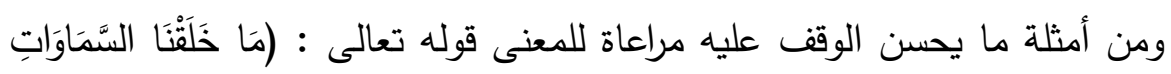

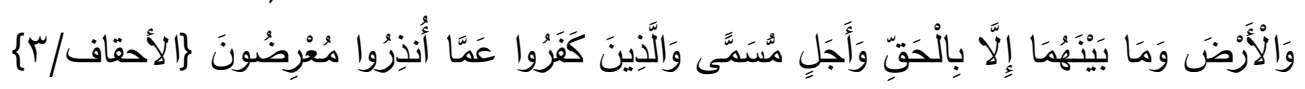

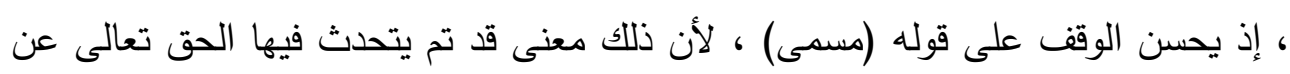

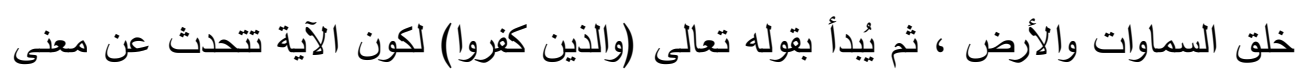

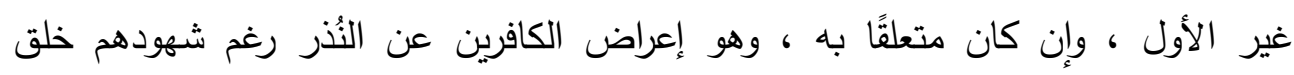
السماوات والأرض ، والوقف والابتداء هنا يسهم في حبك النص من حيث هو مبين لدان لالته ،

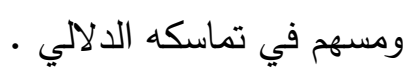

r. الوقف الإعرابي : المقصود هنا مواضع الوقف التي تكون لتتمة أركان الجملة أو اكتمال الجملة الإسنادية ، وليس معنى تخصيص الوقف الإعرابي أنه مخالف للوقف

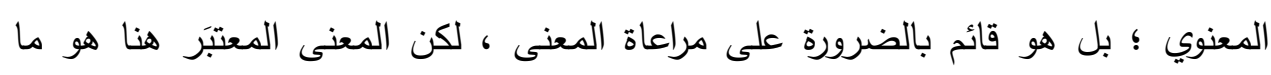

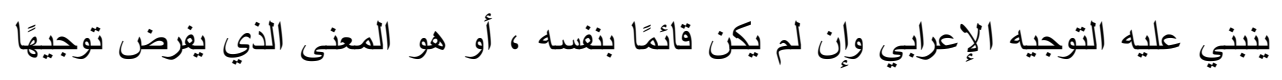
بعينه للإعراب ، يقول ابن جني : "وذلك أنك تجد في كثير من المنثور والمنظوم الإعراب لإبه

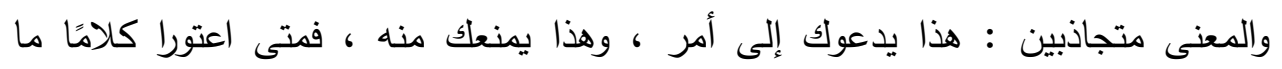




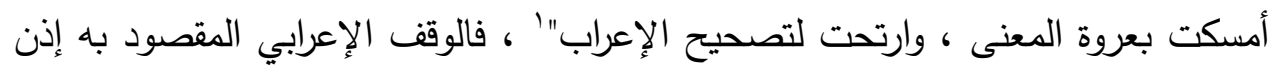

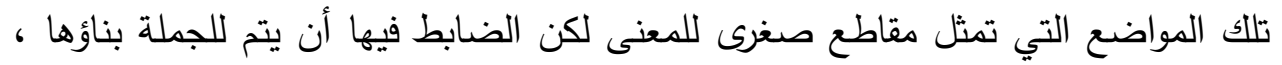

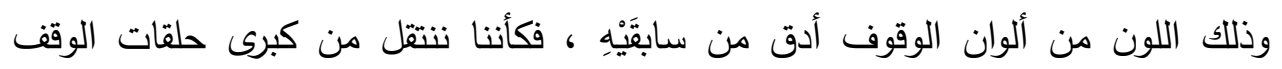
(الوقف الموضوعي) إلى حلقة أدق أو أصغر (الوقف المعنوي) تشتمل عليها الكبرى ، إلى حلقة أدق (الوقف الإعرابي) وهي اللبنة الصغرى للبناء النصي ، وهذا الوقف شائع في القرآن الكريم من أوله إلى آخره ، ومن ذللك آل حم ، ومثله في القرآن الكريم قوله تعالى :

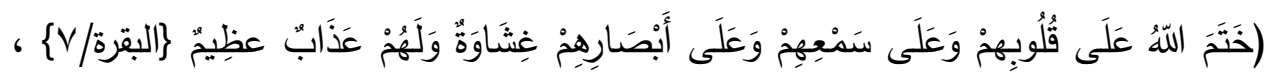
فالوقوف على "سمعهم" لاكتمال الجملة ، فالجار والمجرور والعطف عليه " عَلَى قُلُوبِهْ وَعَلَى سَمْعِهٍِْ" متعلق بالفعل "ختم" ، أما الواو التالية فهي استئنافية ، والجار والمجرور بعدها متعلق بخبر محذوف للمبتدأ المؤخر "غشاوة" ولذلك جاءت مرفوعة ، وهذا اللون من ألوان الوقف هو الوقف الإعرابي الذي يقع داخل المعنى الواحد ، ومنه قوله تعالى : (ذَلَكُعُ

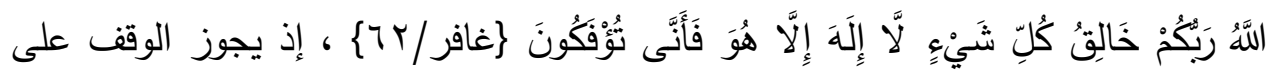

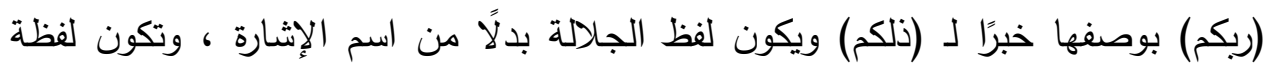
(خالق) خبرًا لمبتدأ محذوف تقديره (هو) ، ويجوز كذلك الوقف على لفظ الجلالة لكونه خبرًا لاسم الإشارة ، ويكون لفظ (ربكم) . عند البدء به ـ مبتدأ ، وخبره (خالق) ، كما يجوز

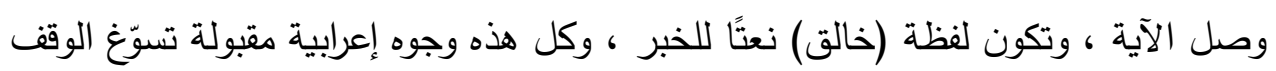

$$
\text { على أيّ من المواضع المذكورة . }
$$

ومن أمثلة هذا الوقوف قوله تعالى : (يُطَافُ عَلَيْهِمِ بِصِحَافٍ مِّن ذَهَب وَأَكْوَابٍ

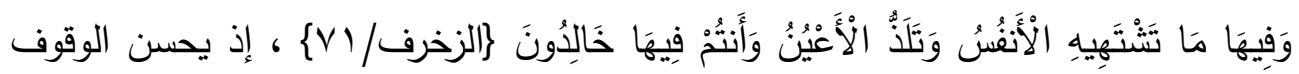

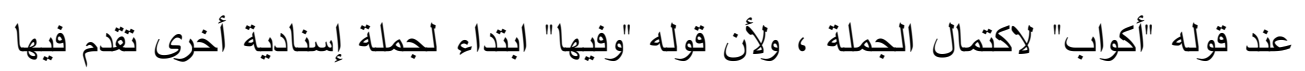

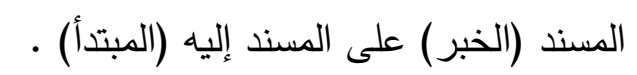

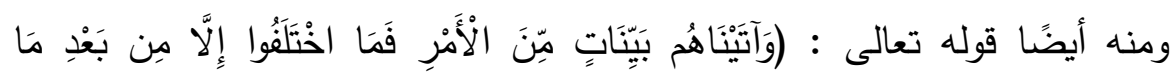

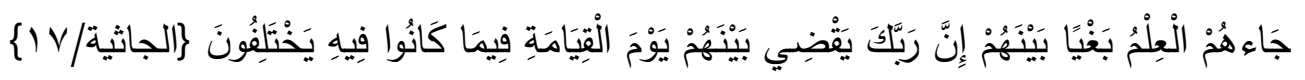

' الخصائص ، roN/T . 


\section{الوقف والابتداء في القرآن الكريم دراسة نصية}

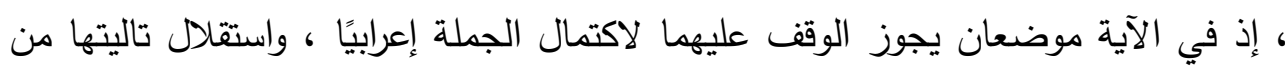

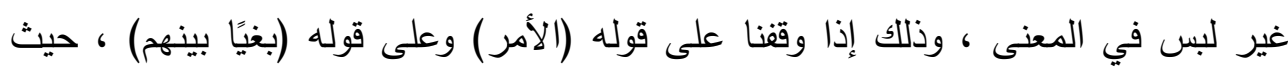
يستوي في الآية الكريمة الوقف على هذين الموضعين ووصلهما من غير تغير في المعنى ،

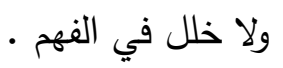

وقد يميز الوقف الإعرابي بين وجوه للالالة عند الوقف والابتداء ، بحيث تتعدد

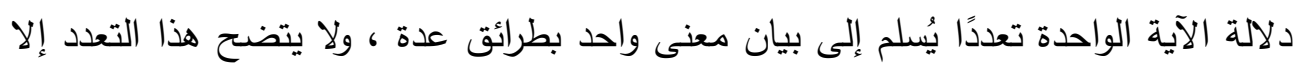

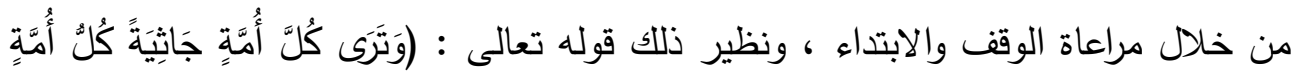

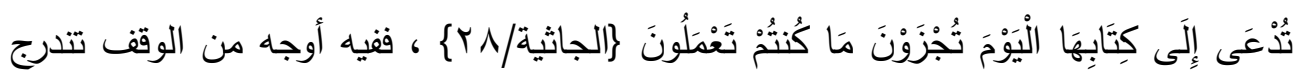

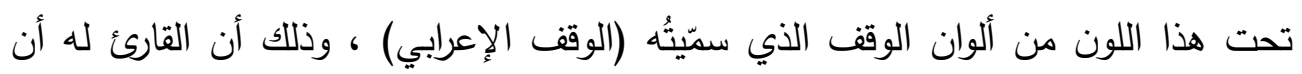

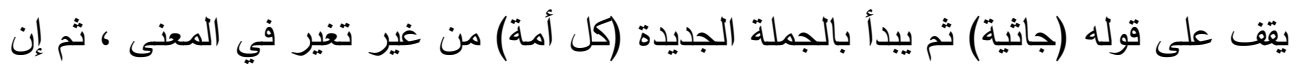

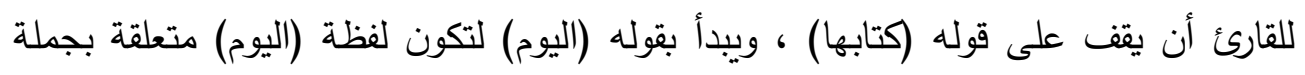

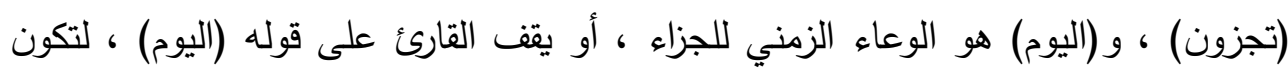

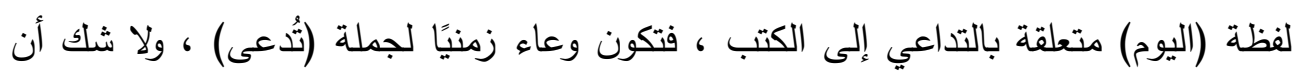
ذللك كله ينصب في أساس المعنى الذي تقصد إليه الئه الآية الكريمة .

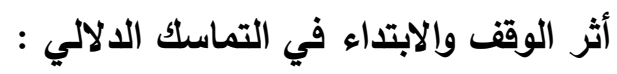

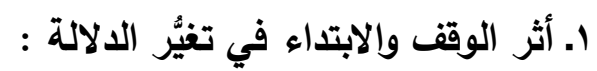
أ ـ تغير الدلالة إلى ما يخالف المراد :

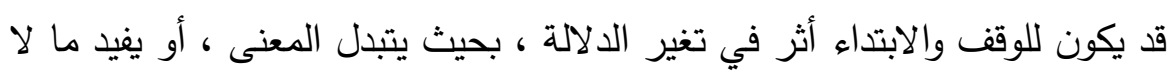

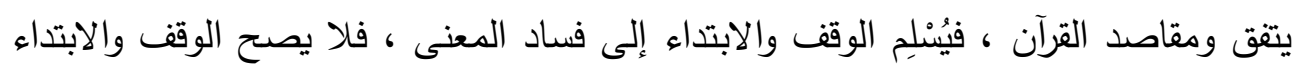

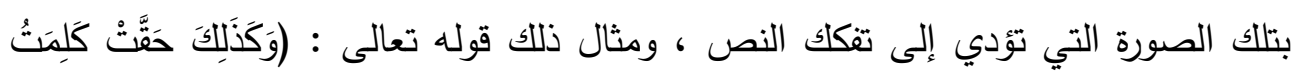

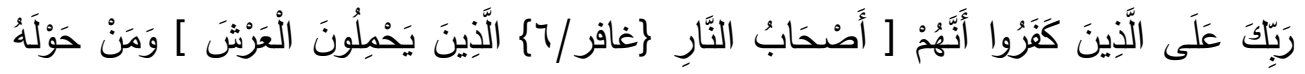

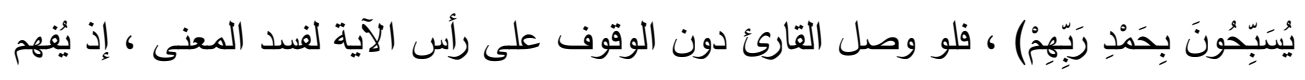

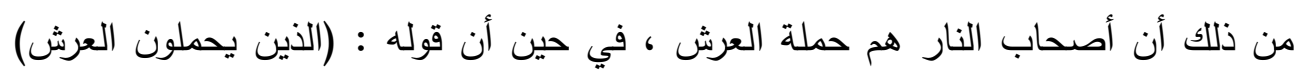

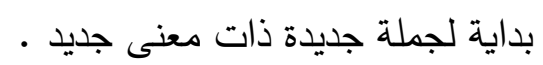




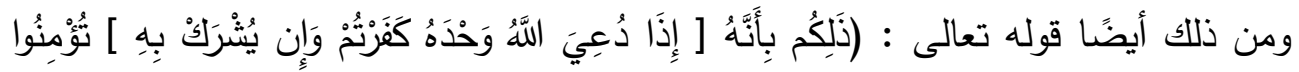

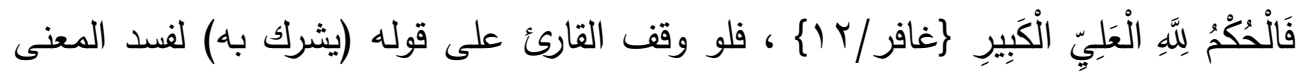

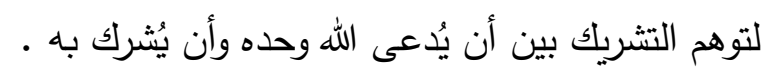

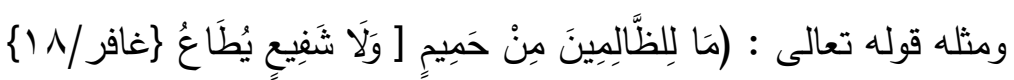

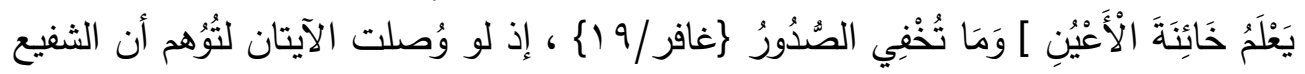

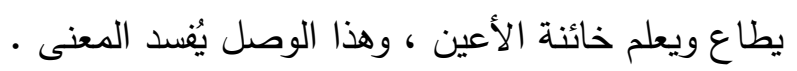

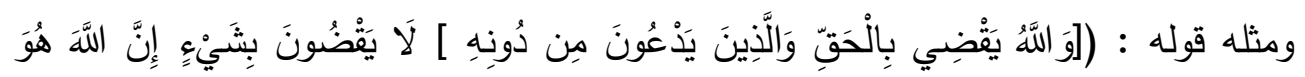

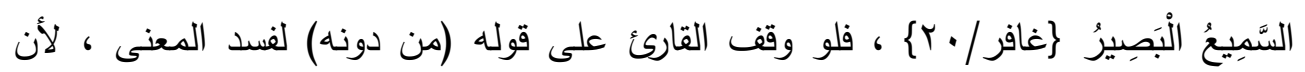

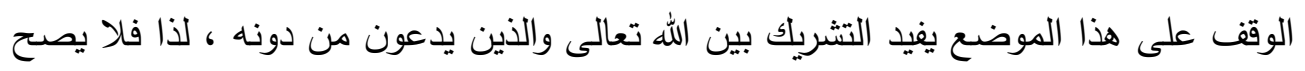
هذا الوقف .

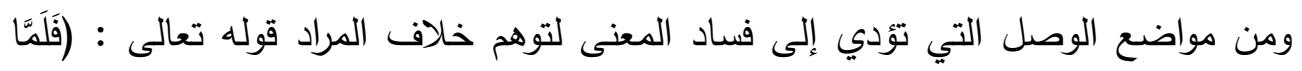

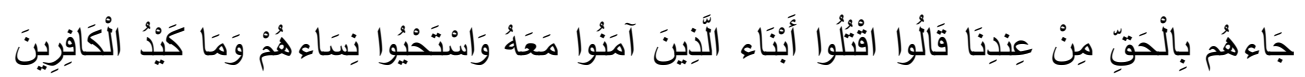

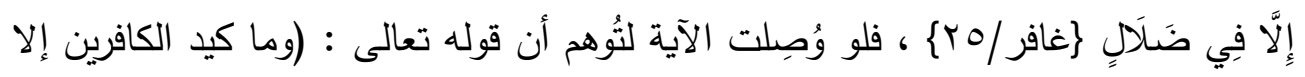

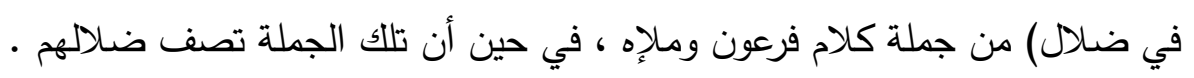

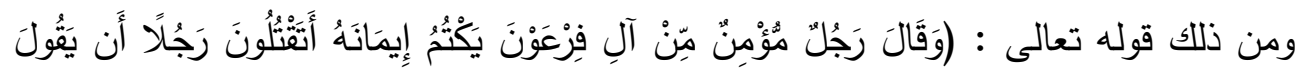

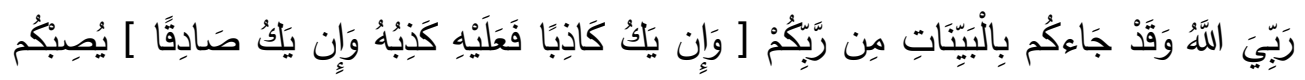

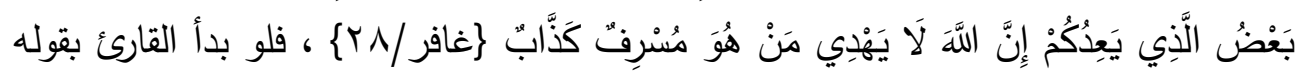

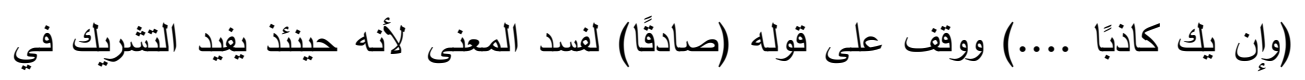
الحكم بين حالة صدقه وكذبه .

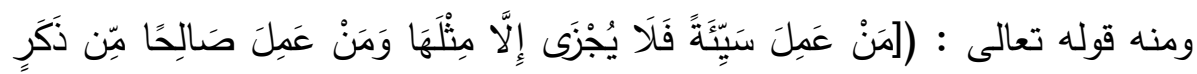

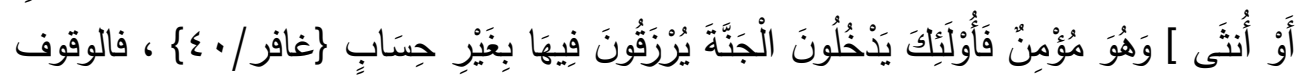

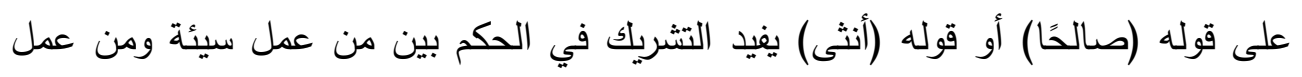
صالحًا ، وهذا الوقوف يفسد المعنى . لماله 
الوقف والابتداء في القرآن الكريم دراسة نصية

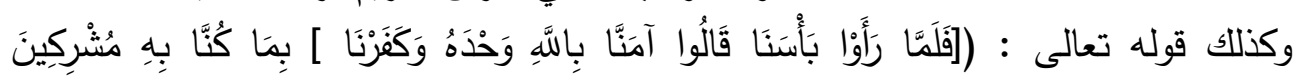

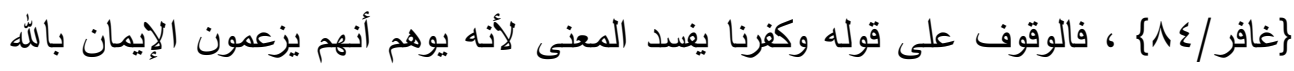

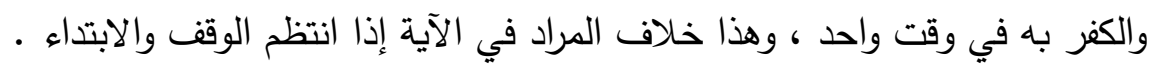

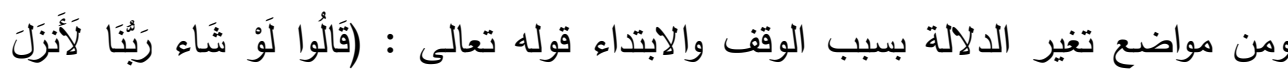

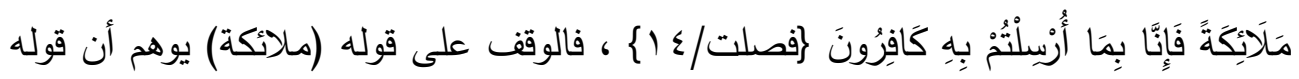

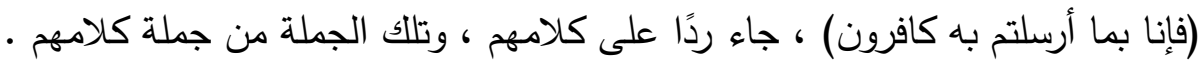

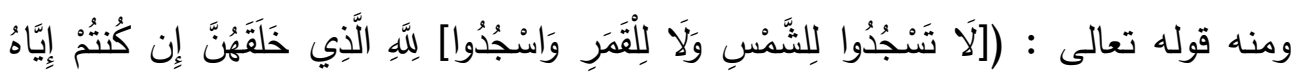

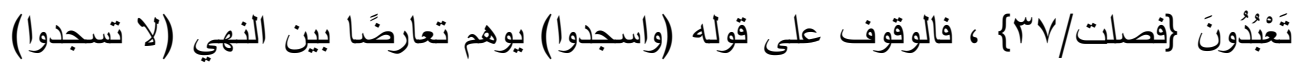

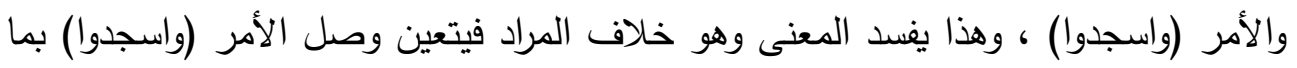

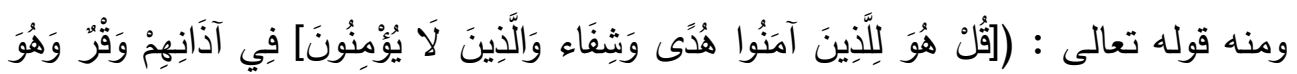

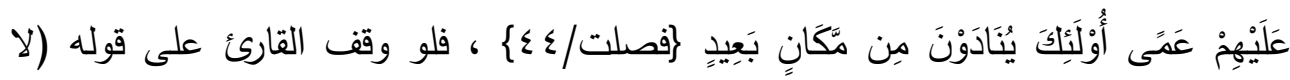

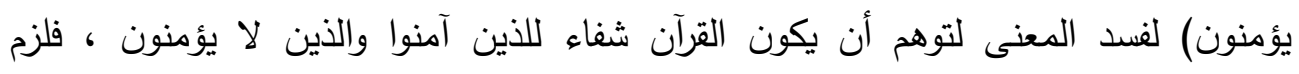
وصلها بما بعدها .

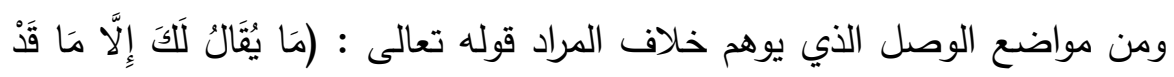

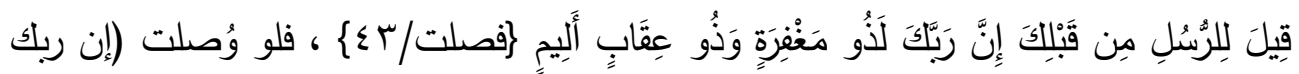

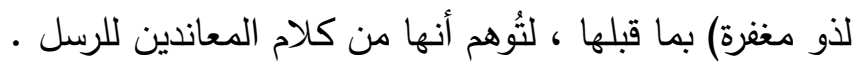

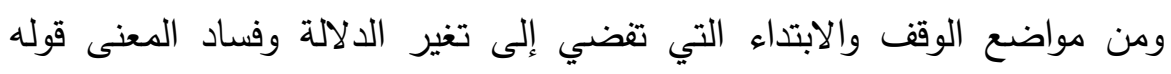

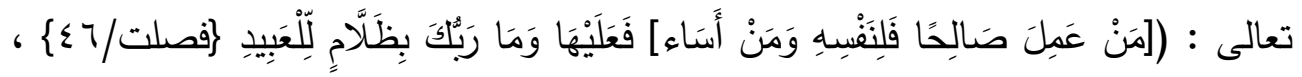

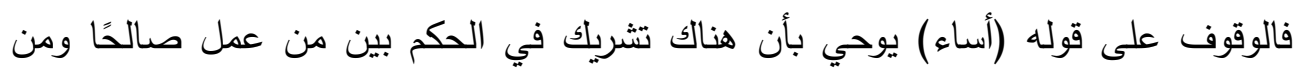
أساء . ومن المواضع التي يؤدي فيها الوقف إلى فساد الدلالة ، قوله تعالى : (أَلَكَ إِنَّ اللَّة

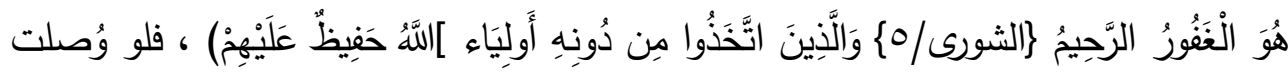


الآيتان ووُقف على قوله (أولياء) لفسد المعنى ، والأولى الوقف على على رأس الآية ثم البدء بالآية السادسة إلى قوله (عليهم) ليفيَ الوقف والابتداء بالمعنى .

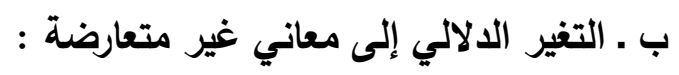

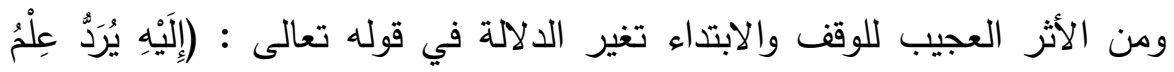

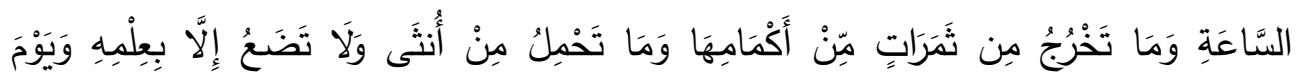

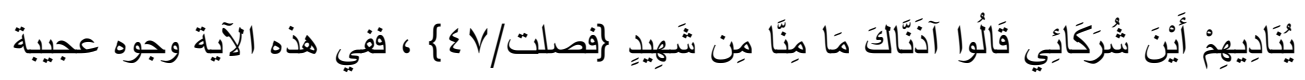

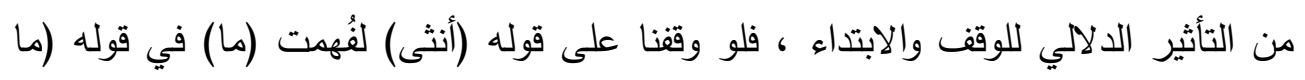
تخرج) وقوله (ما تحمل) على أنها موصولة ، والمعنى أنه تعالى يعلم الساعة ويعلم ما يخرج من الثمار ويعلم ما تحمله الإناث .

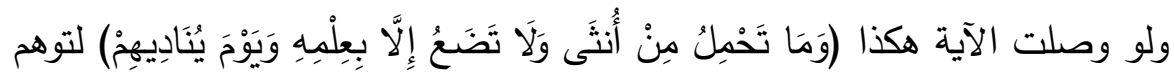

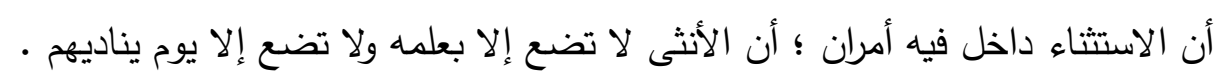

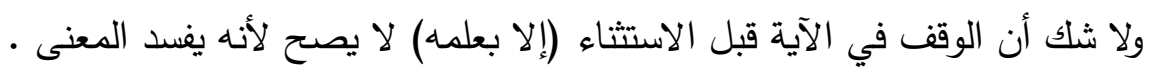

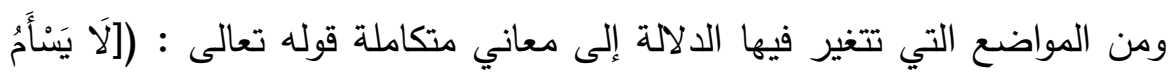

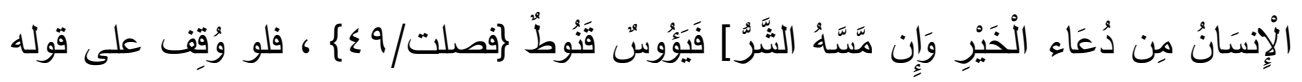

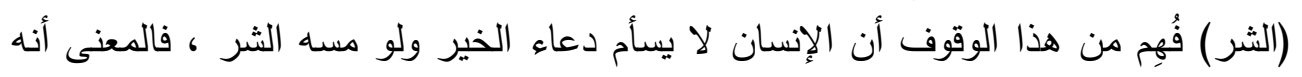

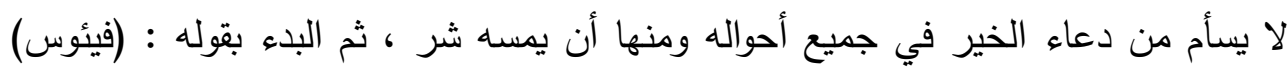
يكون جملة مستقلة كأنها تعليق على حال الإنسان ، أي : فهو يئوس إن لم يكن داعيًا

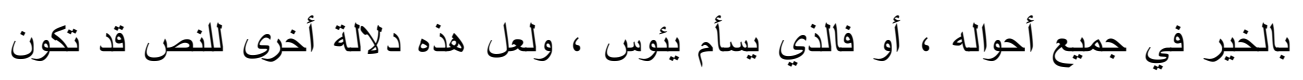

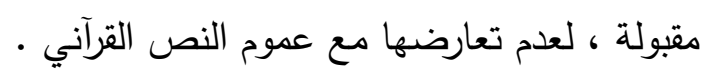

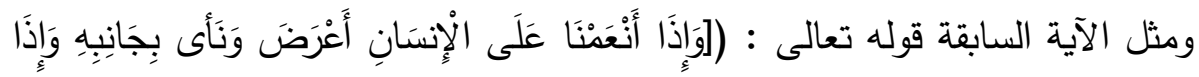

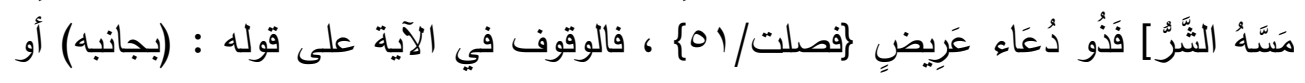
توصل حتى آخرها ، أما الوقوف على قوله : (الشر) فيفيد معنى آخر غير المفهوم من الآية بالوقوف على قوله : (بجانبه) ، والمعنى عند مخالفة ذلك الوقوف المشهور : أن الإنسان

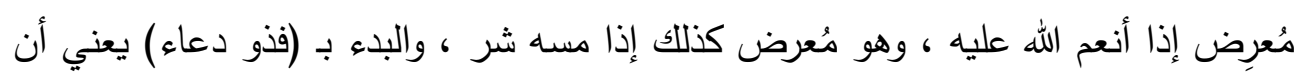


الوقف والابتداء في القرآن الكريم دراسة نصية

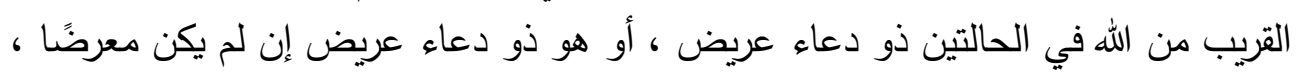

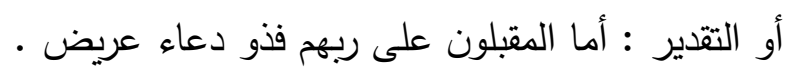

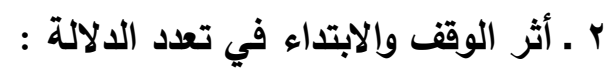

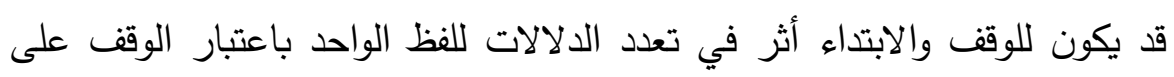

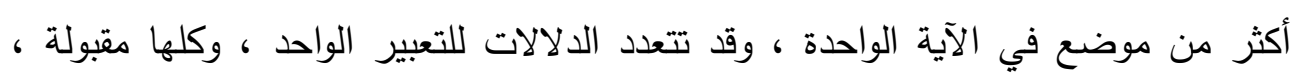

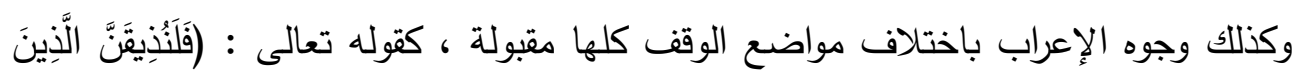

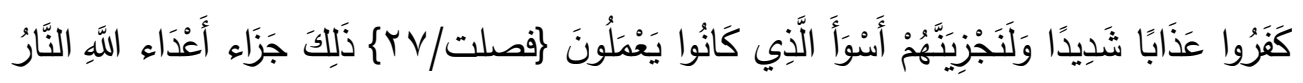

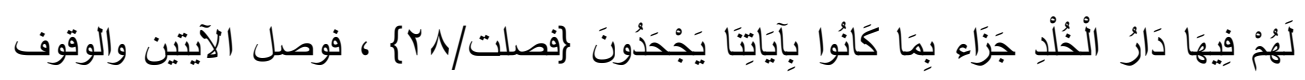

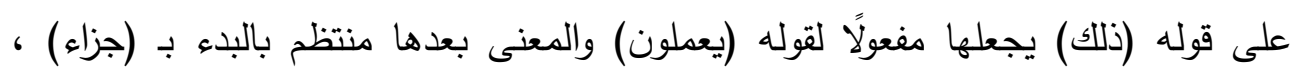

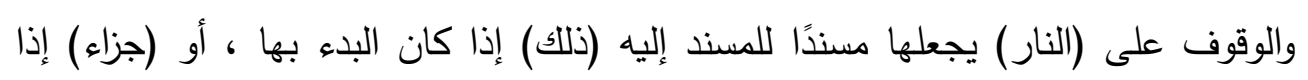

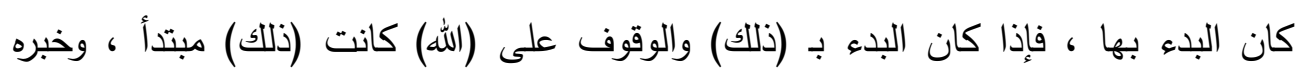

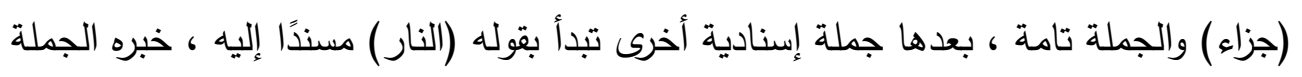

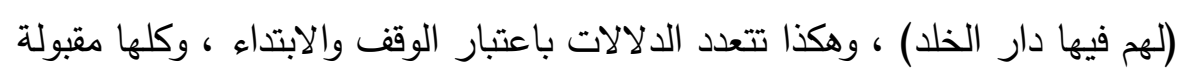

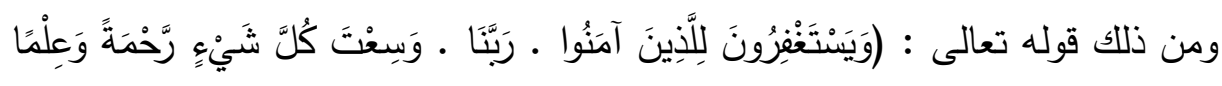

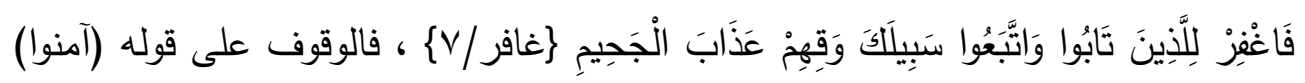

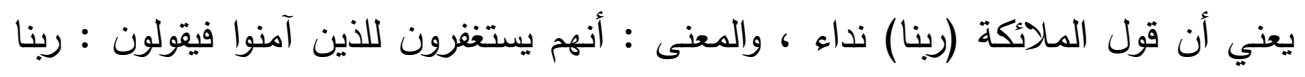

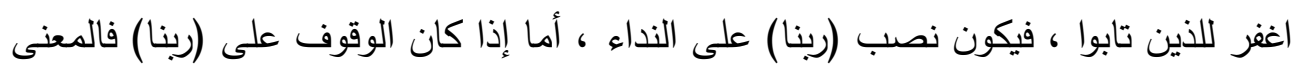

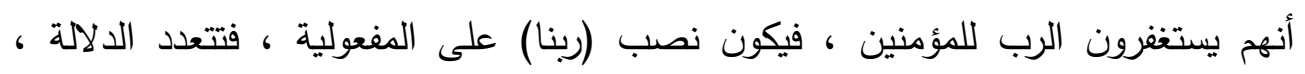

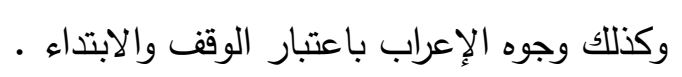

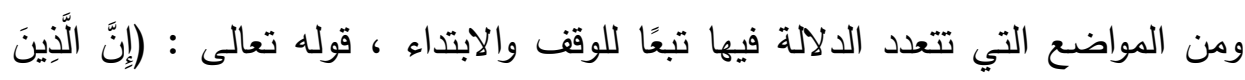

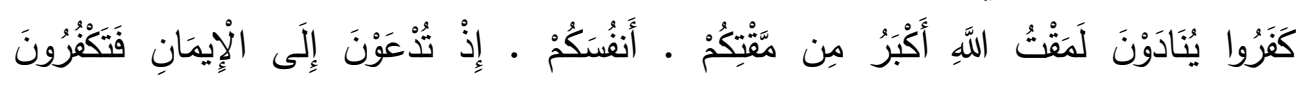

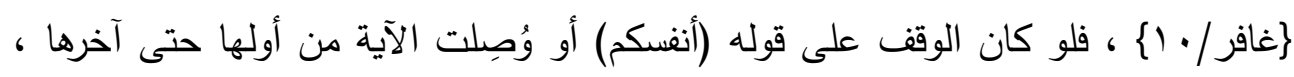

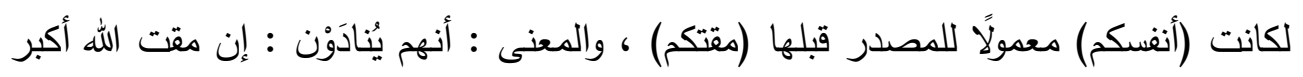

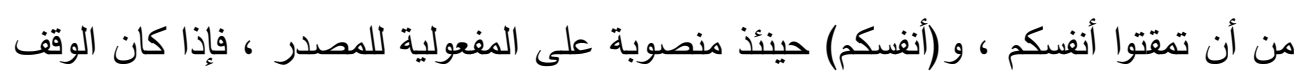


على (مقتكم) ، والبدء بـ (أنفسكم) ، لزم تقدير ناصب علب لـ (أنفسكم) فيكون المعنى : إن مقت

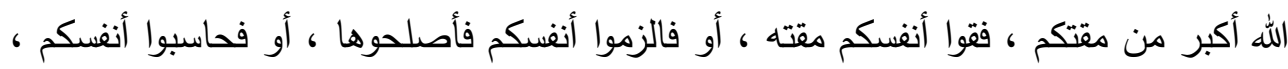

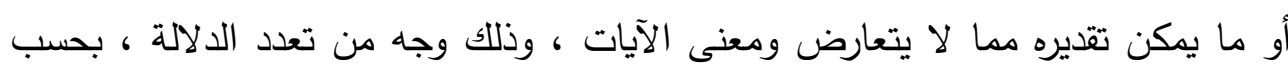

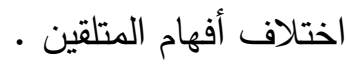

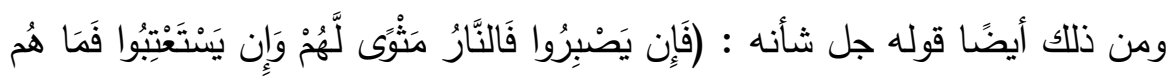

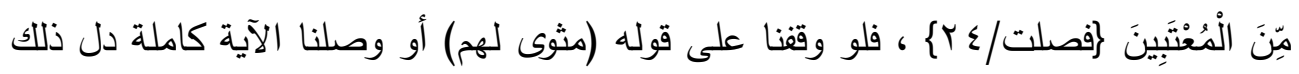

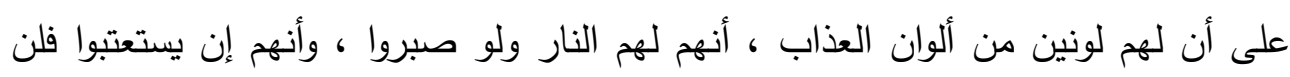

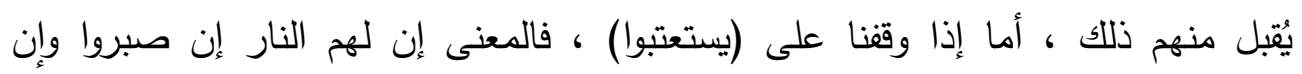
استعتبوا ، ويُعقب القرآن على حالهم حينئذ فيقول : (فما هم من المعتبين) .

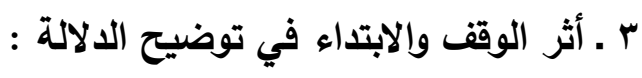

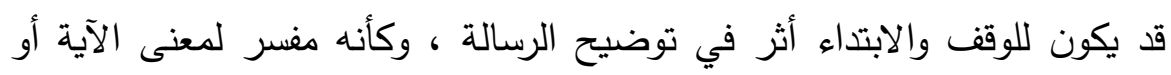

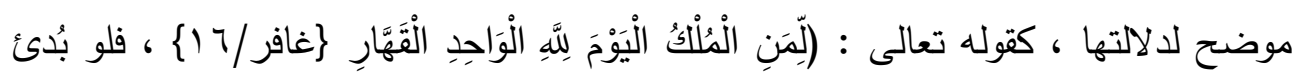

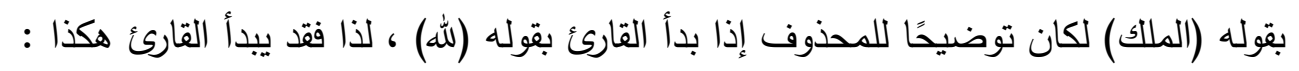

$$
\text { لمن الملك اليوم ؟ المان توطيج }
$$

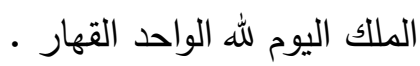

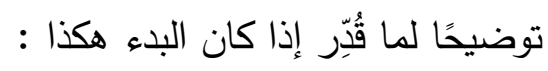

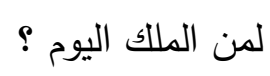

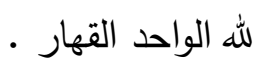

ومن المواضع التي تتضح الدلالة فيها بمراعاة الوصل قوله تعالى : (وَلََََْ أَرْنَلْنَا

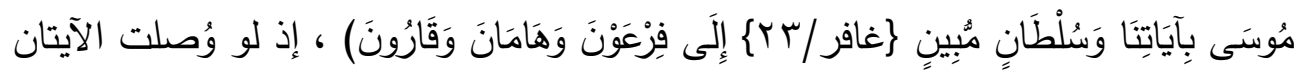

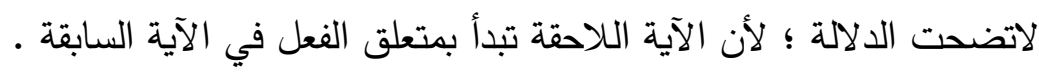

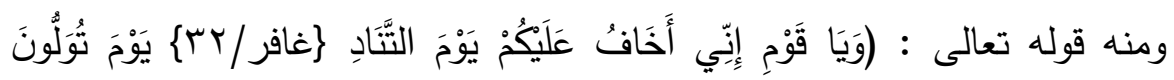

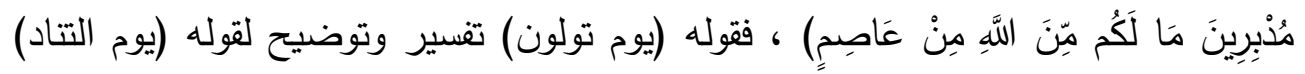
فيكون في وصل الآيتين توضيح للدلالة . 
الوقف والابتداء في القرآن الكريم دراسة نصية

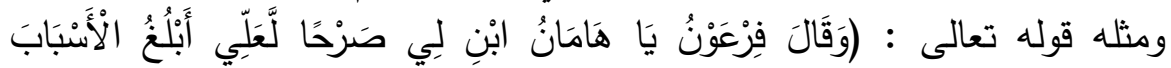

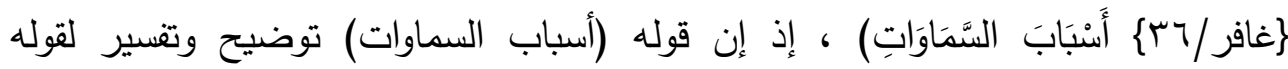

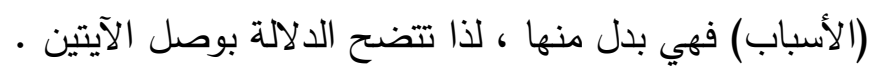

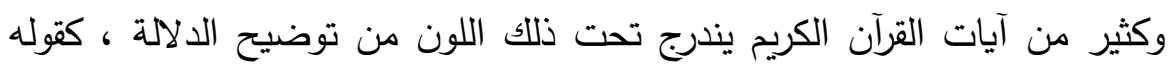

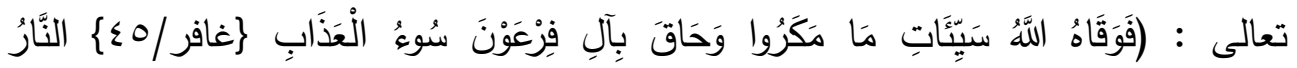

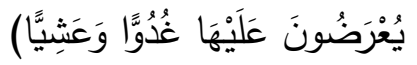

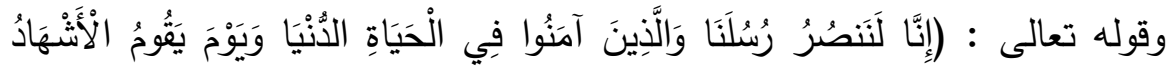

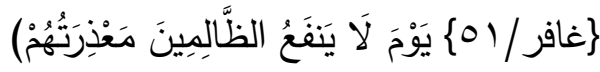

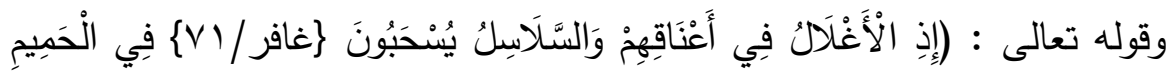
نُمَّة فِي النَّارِ يُسْجَرُونَ

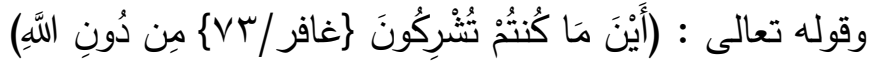

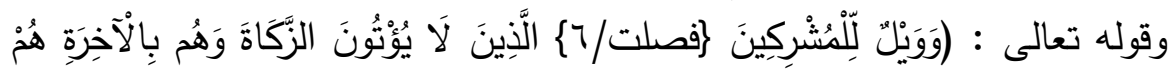

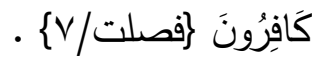

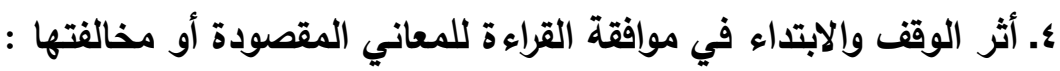

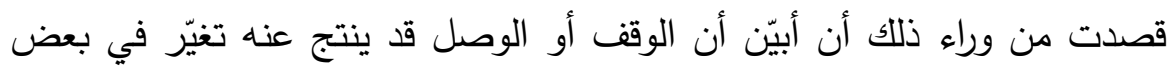

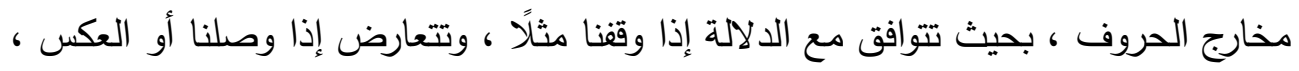

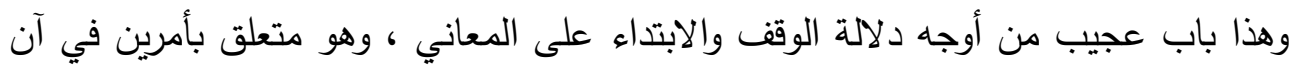

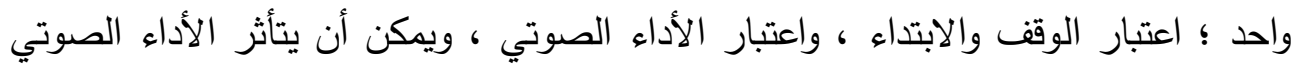

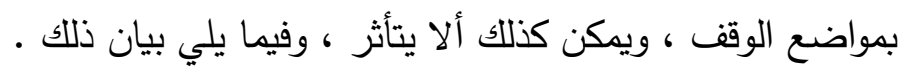

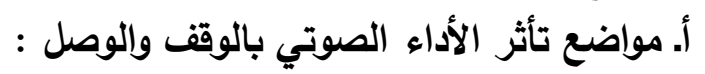

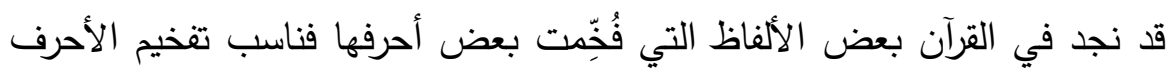

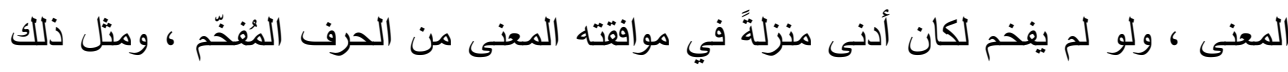

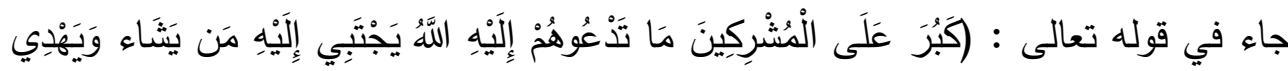

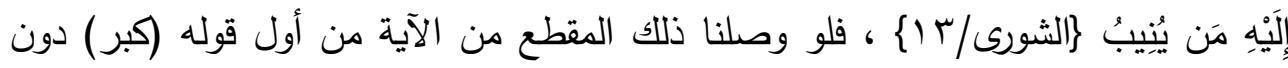

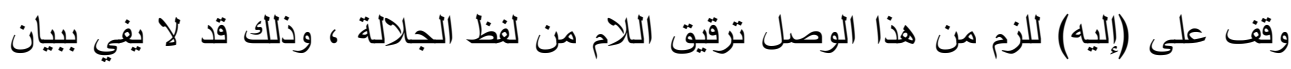

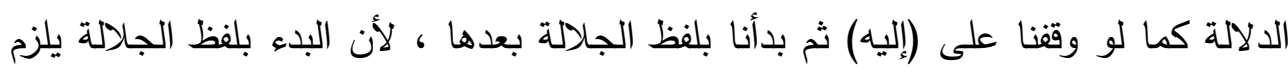

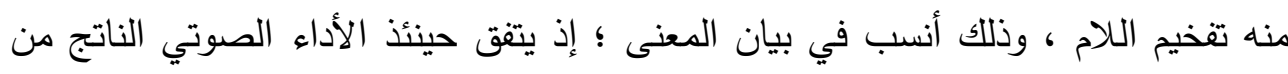




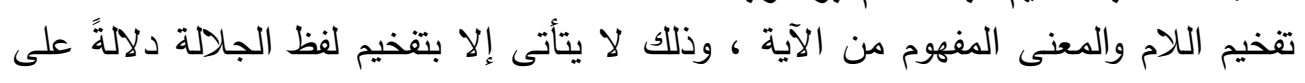

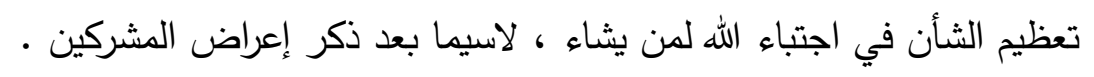

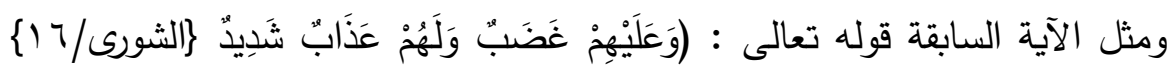

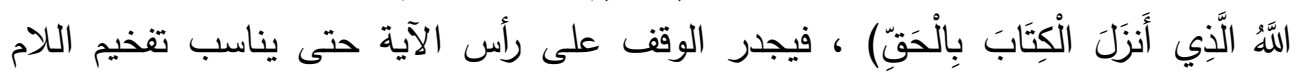

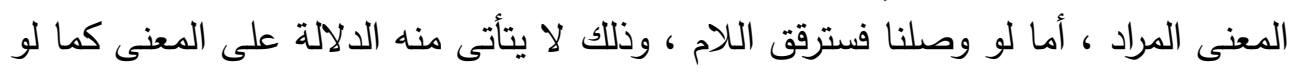

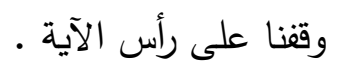

ومن تلك المواضع كذلك قوله تعالى : (أَلَا إِنَّ الَّذِينَ يُمَارُونَ فِي السَّاعَةِ لَفِي ضَلَالٍِ

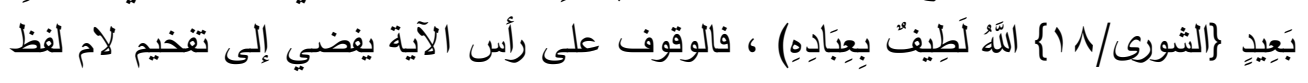

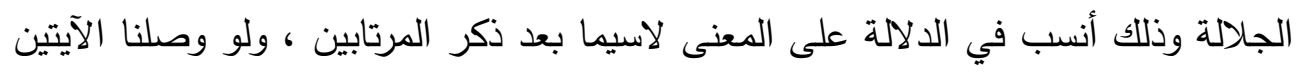

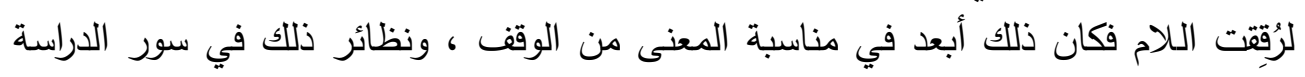

\section{ب ـ مواضع استواء الوقف والوصل :}

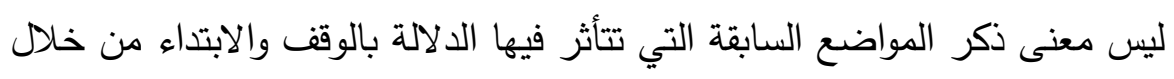

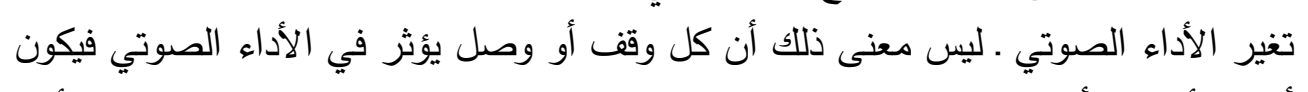

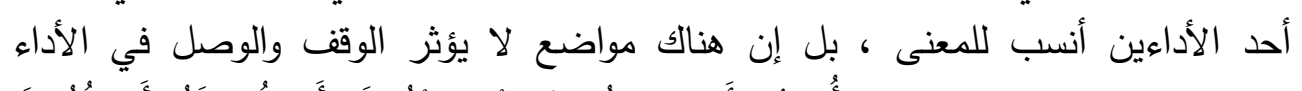

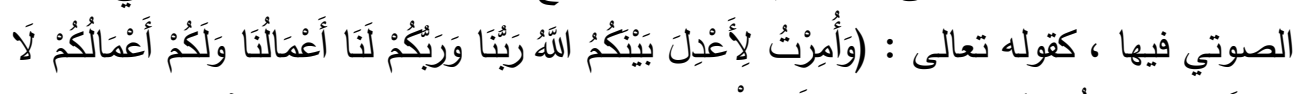

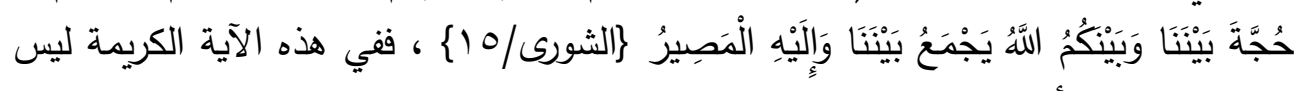
للوقف والابتداء أثر في موافقة المخِرج للمعنى ، فلو وقفنا على قوله (بينكم) في موضعيها

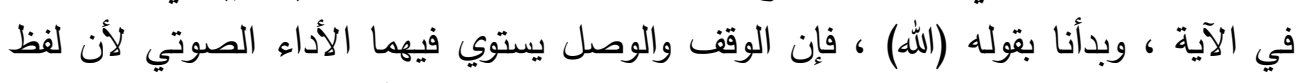

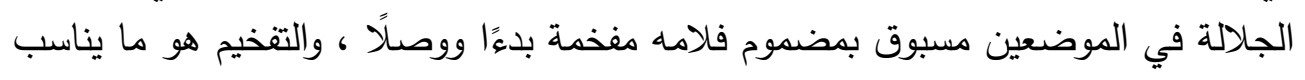

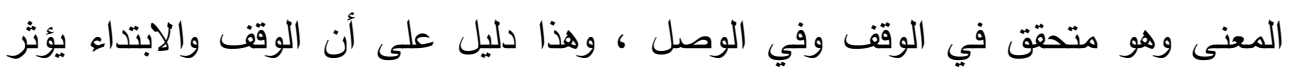

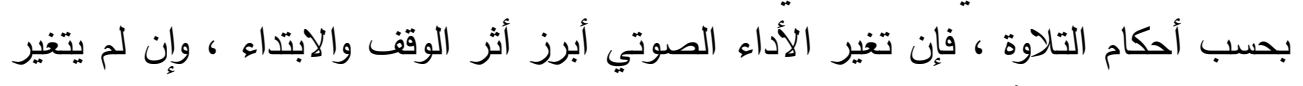

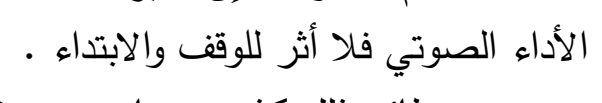

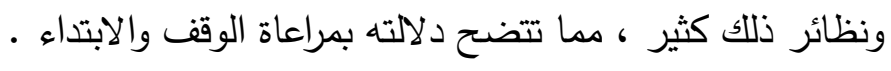

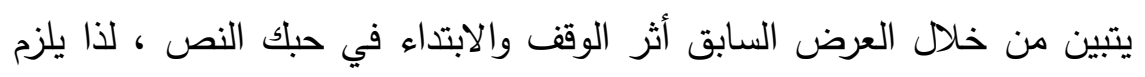

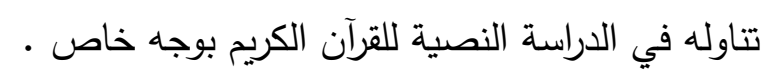

